\title{
Influence of hydrothermal recharge on the evolution of eruption styles and hazards during the 2018-2019 activity at Kuchinoerabujima Volcano, Japan
}

\author{
Yusuke Minami ${ }^{*}$ Keiko Matsumoto, Nobuo Geshi and Hiroshi Shinohara
}

\begin{abstract}
The activity of the 2018-2019 eruption of Kuchinoerabujima Volcano in Japan changed from continuous ejection of ash-laden plumes between October 21 and the middle of December, to intermittent explosive activity accompanied by several pyroclastic density currents until January 2019. To understand the behaviors of magma and hydrothermal fluid that controlled the eruptive sequence, we carried out component analysis, X-ray diffractometry, and leachate analysis for ash samples. The proportion of non-altered volcanic ash particles is $\sim 15 \%$ in the earlier phase, then it decreased to less than $10 \%$ in the later explosive phase. Accordingly, the mineral assemblage of the volcanic ash samples changed from plagioclase-dominant to sulfate minerals-dominant. Concentration of $\mathrm{SO}_{4}{ }^{2-}$ and $\mathrm{Cl} / \mathrm{SO}_{4}$ values of the ash-leachates decreased toward the later activity. These results indicate that the proportion of fresh volcanic rocks decreased and sulfuric acid fluid-derived sulfate minerals increased toward the later activities. Consequently, the 2018-2019 eruption at Kuchinoerabujima Volcano changed from magmatic activity to phreatomagmatic activity. Weak glowing of the crater was observed during the magmatic activity, indicating the volcanic conduit was hot enough to dry up the sub-volcanic hydrothermal system. The following phreatomagmatic activity indicates that the hydrothermal fluid recharged after the magmatic eruption phase. Recharge of the hydrothermal fluid likely caused the variation of the eruption style, and is a process that may control the evolution of hazards during future eruption scenarios at similar active volcanoes in Japan and worldwide.
\end{abstract}

Keywords: Eruptive sequence, Phreatomagmatic eruption, Sulfate minerals, Ash leachate, Hydrothermal alteration, Volcanic hazards, Kuchinoerabujuma Volcano

\footnotetext{
*Correspondence: y.minami@aist.go.jp

Geological Survey of Japan, AIST, 1-1-1 Higashi, Tsukuba, Ibaraki 305-8567,

Japan
} 


\section{Graphical Abstract}

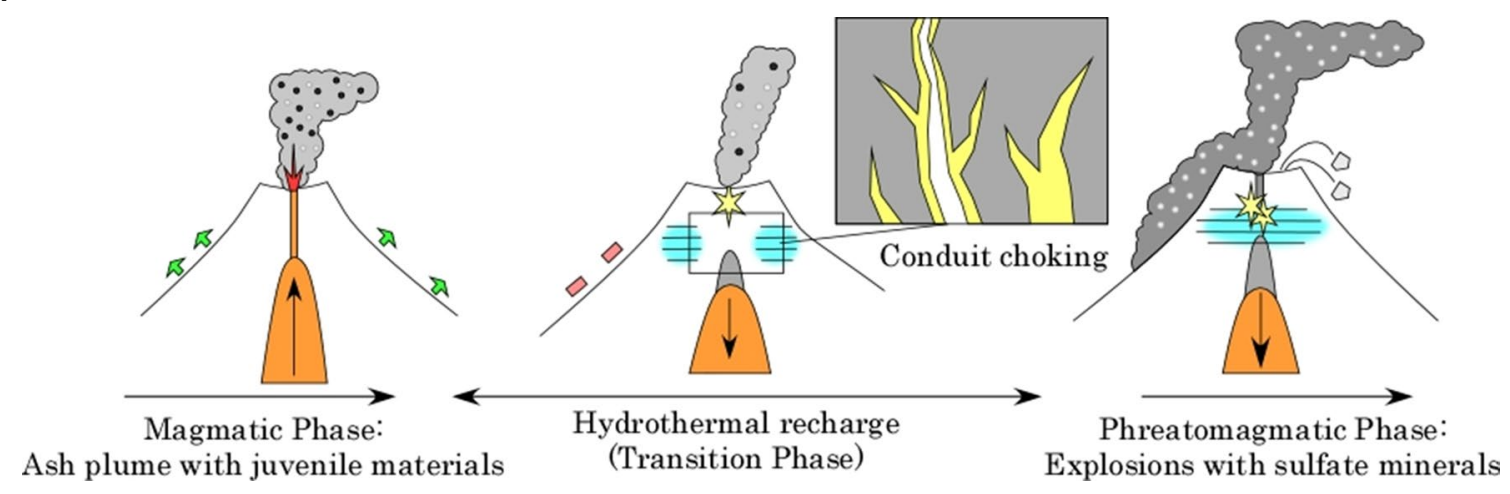

\section{Introduction}

Phreatic and phreatomagmatic eruptions at subaerial volcanoes are often small-scale and are frequently accompanied by pyroclastic density currents (PDCs). In particular, for volcanoes without a volcanic lake or meteoric water inflow, phreatic and phreatomagmatic eruptions are considered to be triggered by interactions between magma intrusion and hydrothermal fluids or overpressure of a hydrothermal system (Wohletz and Heiken 1992; Schmincke 2004; Stix and Moor 2018). When a magmatic eruption occurs at a volcano with a hydrothermal system, eruption styles become more complicated because they are controlled by ascending magmas and interaction between the magma and hydrothermal fluids (Tarff and Day 2013; Uesawa 2014). Recently, Németh and Kósik (2020) outlined some definitions about hydrovolcanism on land. Following their recommendations, the term "phreatomagmatic" means a volcanic eruption triggered by the direct interaction of ascending magma and groundwater. On the other hand, "phreatic" and "hydrothermal" eruptions are volcanic eruptions that are triggered by the indirect interaction of ascending magma and groundwater or hydrothermal fluids. In such eruptions, volcanic ejecta usually contains hydrothermally altered material which is derived from sub-volcanic hydrothermal alteration zones (Ohba and Kitade 2005; White and Ross 2011; Minami et al. 2016; White and Valentin 2016; Geshi and Itoh 2018). The character and behavior of the hydrothermal fluid and relationship with volcanic activity, however, are often not clear, because direct observation of the sub-volcanic hydrothermal system and/ or the hydrothermal fluid during eruption is impossible. Additionally, precursory phenomena of a phreatic or phreatomagmatic eruption such as ground deformation and volcanic tremor are usually unclear until the time of eruption (Dempsey et al. 2020; Caudron et al. 2021). From the viewpoint of preservation in geological records, the volumes of volcanic ejecta from some phreatic or phreatomagmatic eruptions are quite small (less than $\mathrm{VEI}<1$ ), making it very difficult to examine the temporal variations of the hydrothermal system, character of the hydrothermal fluid, relationship with the volcanic activity for past eruptions, and the recurrence time of phreatic eruptions.

Therefore, to understand an eruptive sequence at such a volcano, it is necessary to understand behaviors both of magmas and hydrothermal fluids. In this study, we focused on the volcanic ash of the 2018-2019 eruption at Kuchinoerabujima Volcano in southwestern Japan, which hosts a hydrothermal system, to understand the interaction between ascending magma and hydrothermal fluids. Component analysis, mineral assemblage description, and ash-leachate analysis were carried out for ash samples collected continuously throughout the 3-month eruption sequence. As a result, this high-resolution investigation revealed that the eruption transitioned from magmatic to phreatomagmatic activity, driven by the interaction between magma and hydrothermal fluids. The eruptive sequence proposed in this study is important for the improvement of understanding the mechanisms of phreatomagmatic eruptions and for efforts to prevent volcanic disasters.

\section{Background of Kuchinoerabujima Volcano}

Kuchinoerabujima Volcano is an active volcano located on the northern part the Ryukyu arc, southwestern Japan (Fig. 1). Kuchinoerabujima Volcano has a WNWESE elongated conical edifice with $\sim 1.2 \mathrm{~km}$ height from the surrounding sea floor. The subaerial part of the edifice forms a volcanic island named Kuchinoerabujima, with a length of $12 \mathrm{~km}$ and a maximum height of $657 \mathrm{~m}$ above the sea level. The population of the island is about 150 in $2010 \mathrm{AD}$. Most of the inhabitants live in 


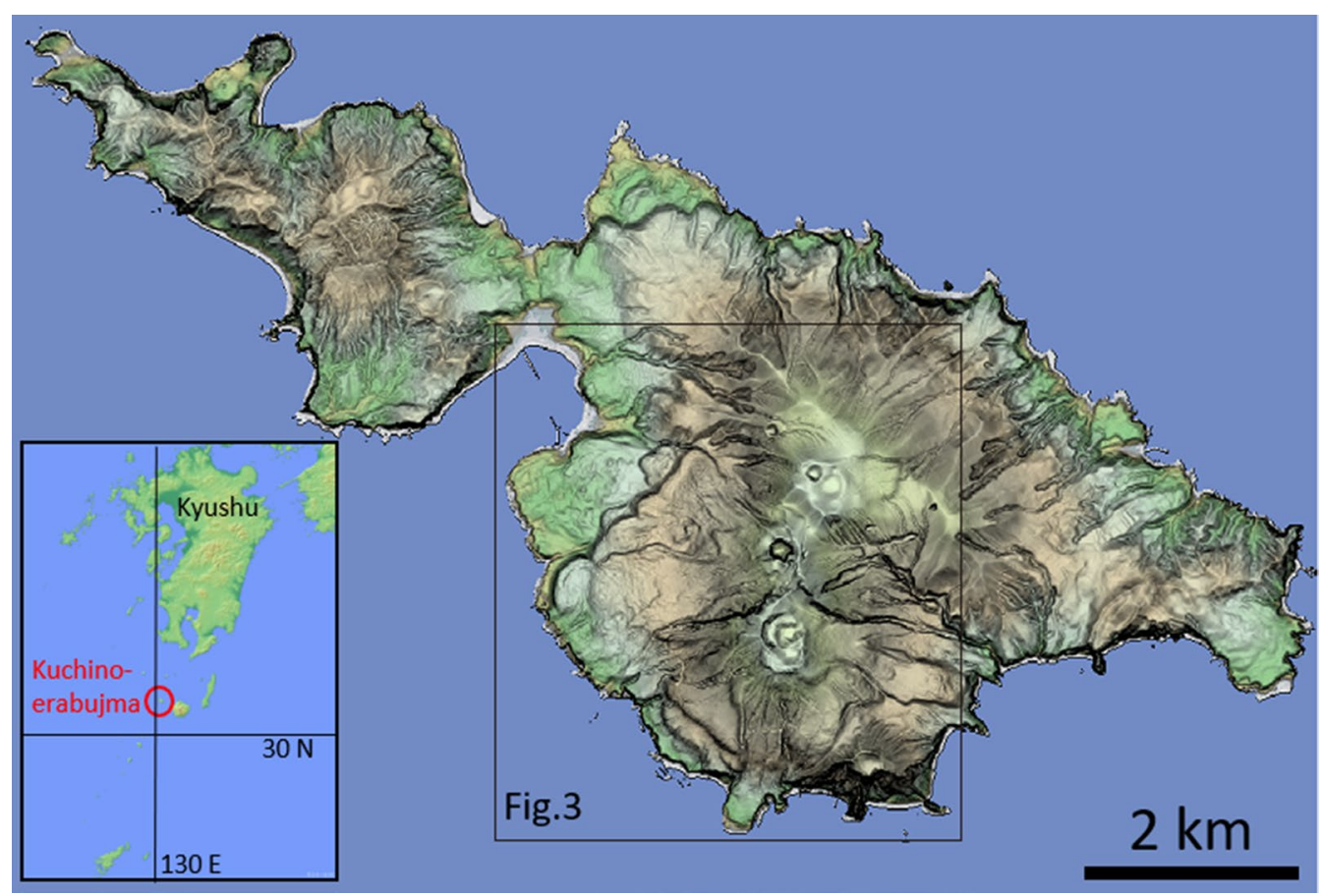

Fig.1 Topographic map of the Kuchinoerabujima Island. The relief map was created using the 10-m-mesh digital elevation model provided by Geospatial Information Authority of Japan

the main village (Honmura), located $\sim 3 \mathrm{~km} \mathrm{NW}$ of the summit crater of Shindake.

The edifice of Kuchinoerabujima Volcano is a cluster of several volcanic sub-edifices (Geshi and Kobayashi 2007). The subaerial part of the volcanic edifice is primarily composed of andesitic lava and pyroclastic deposits, although small amounts of basaltic lavas are also present. Among them, Shindake and Furudake, situated at the central portion of the island, are the active volcanic centers which have erupted in the Holocene. Furudake is a composite volcanic cone that started to grow around $13 \mathrm{ka}$. Several sector collapses have divided the edifice of Furudake. Though no historical eruption from Furudake has been recorded, a block and ash flow deposit distributed on the eastern flank, one of the youngest deposits from Furudake, is dated at 200 years ago (Geshi and Kobayashi 2007). Furudake has a circular crater with a diameter of $\sim 400 \mathrm{~m}$ across at the summit.

Shindake is the youngest edifice on the island. The main part of the edifice comprised andesitic lava flows which erupted $\sim 1000$ years ago (Miki et al. 2002), covered by beds of the volcanic breccia produced by the recent phreatomagmatic-phreatic explosions. Shindake has a circular crater with a diameter of $\sim 300 \mathrm{~m}$ across at its summit, and several $\mathrm{N}-\mathrm{S}$-trending eruption fissures. All known historic eruptions since the middle of nineteenth century occurred at Shindake (Geshi and Kobayashi 2007; Geshi and Itoh 2018).

Active geothermal areas and fumaroles at the summit of Shindake and Furudake indicate the presence of an active hydrothermal system within the volcanic edifice (Shinohara et al. 2011). Frequent phreatic-phreatomagmatic explosive activities have formed thick layers of explosion breccia with many hydrothermally altered components at the summit area of Shindake and Furudake.

\section{Recent eruptive activities of Shindake}

The historical eruptions of Shindake, which are limited within the last 200 years, can be grouped into four active periods: the middle of the nineteenth century, the 1930s, from 1966 to 1980, and the ongoing activities since 2014 (Geshi and Kobayashi 2007; Geshi and Itoh 2018). Because of the scarcity of written records, little is known about the eruptive activity in the nineteenth century. During the activity of the 1930s, intense explosions damaged facilities of sulfur mines in and around the summit crater of Shindake. An explosive eruption on December 24,1933 destroyed a village $1.7 \mathrm{~km}$ east of the crater, causing 8 deaths and seriously injuring 27 others. The activities of the 1960-1970s eruptions are also characterized by intense phreatic-phreatomagmatic explosions. Ballistic blocks reached up to $3.5 \mathrm{~km}$ from the summit 
crater during the eruption on November 22, 1966. After the 1966 eruption, small eruptions occurred intermittently from the crater of Shindake through the 1970s. The series of eruptions was terminated by a phreatic eruption on September 28, 1980.

The eruptive activity at Shindake resumed with the eruption on August 3, 2014, following a 34-year hiatus. Prior to the resumption of eruptive activity, long-term inflation of the edifice, intermittent rise of seismic activity, and increased fumarolic activity were observed since the 2000s. Three major explosive eruptions and several minor ash emissions were recorded from 2014-2015. The first eruption occurred on August 3, 2014, from newly formed fissures in the eastern and western part of the summit crater of Shindake (Nakamichi et al. 2017). A minor PDC flowed along the western slope of the volcano and reached the coastline $\sim 2.2 \mathrm{~km}$ from the crater. The second explosions occurred on May 29, 2015 from the summit crater. Low-temperature PDC flowed down all directions from the summit crater and reached $\sim 3.5 \mathrm{~km}$ from the summit crater (Geshi and Itoh 2018). The third eruption occurred on June 19, 2015 (Nakamichi et al. 2017). After the eruption in June 2015, no major eruption occurred until October 2018.

\section{Sequence of the 2018-2019 activity}

The 2018-2019 activity can be divided into four phases (Fig. 2; Sugai et al. 2019). Phase 1 (July 2018 to October 21 ) is characterized by inflation and increased degassing activity. The inflation was detected by GNSS during July-August, following a gradual deflation after the 2015 eruption (Japan Meteorological Agency [JMA], 2018). Flux of $\mathrm{SO}_{2}$ increased from $<500$ ton/day in July to $\sim 1500$ ton/day in the middle of August, and then reached $\sim 1700$ ton/day in September. The seismic activity beneath the summit crater of Shindake increased since the second week of October. No ash emission was observed in Phase 1 (Fig. 3).

Phase 2 (October 21 to the early November) is characterized by intermittent emissions of ash plumes with intense degassing from the summit crater. The emission of ash-laden plumes from the summit crater started on October 21, followed by intermittent pulses of ash plume emissions with typical intervals between minutes and hours. Height of the ash-laden plumes reached $\sim 1000 \mathrm{~m}$ above the crater rim in October-November (Fig. 3). The intensity of seismic activity increased with time. Weak glowing was observed at the summit crater by high-sensitivity monitoring camera from October to the middle of November. The $\mathrm{SO}_{2}$ flux was 500-1000 ton/day during Phase 2.

Phase 3 (from middle November to December 18) is characterized by a decrease of the $\mathrm{SO}_{2}$ flux $(\sim 500$ ton/ day in December) and increase of the seismic and infrasonic activities with intermittent ash-emissions. The plume height increased up to $2100 \mathrm{~m}$ above the crater rim at the end of November, and then decreased to less than $1000 \mathrm{~m}$. Glowing of the crater was not observed since the middle of November. Seismic activity beneath the summit crater peaked at the middle of November and then decreased. Weak infrasonic waves with the emission of ash plume were detected from November to the first week of December. The inflation of the edifice observed from July ceased in November. The intermittent ash emission ceased on December 13.

Phase 4 (December 18, 2018-February, 2019) is characterized by the occurrence of explosive phreatomagmatic eruptions. Explosive eruptions accompanying ejection of ballistic blocks and strong infrasonic waves occurred at the summit crater on December 18, 28, January 17, 29, and February 2 (Figs. 2 and 3). The eruptions on December 18, January 17 and 29 produced pyroclastic flows (Fig. 3). The eruption on January 17 was the largest event during this period. The eruption column rose up to $6 \mathrm{~km}$ above the crater, and ballistic blocks reached $1.8 \mathrm{~km}$ from the crater. The PDCs flowed down to northwestern, southwestern, and eastern flanks and reached maximum $1.9 \mathrm{~km}$ from the crater (Fig. 3). Though sporadic minor wildfires were recognized in the area covered by the PDC on January 17, no major forest fires or carbonization of tree was observed in the areas covered by the PDCs, indicating that the temperature of the PDC deposits were lower than the ignition temperature of $\operatorname{wood}\left(200-260^{\circ} \mathrm{C}\right)$. The $\mathrm{SO}_{2}$ flux was maintained at $<500$ ton/day though pulse-like increases of the emission were observed after explosions.

\section{Sampling and methods}

The volcanic ash samples of the volcanic activities during 22 October 2018 to 29 January 2019 were collected from Kuchinoerabujima island within a few hours to a day after the explosions without eluting to rains by Fukuoka Regional Headquarters, JMA and provided to Geological Survey of Japan (GSJ), AIST. The authors selected 11 samples for component analysis, X-ray diffractometry (XRD), and ash-leachate analysis (Table 1).

For characterization of mineral assemblage of ash containing water-soluble components, bulk ash samples were analyzed by the XRD (RINT2500; Rigaku Corp.) installed at GSJ, AIST. Ash samples for XRD were dried under $40{ }^{\circ} \mathrm{C}$ for $12 \mathrm{~h}$ and powdered by an agate mill. A randomly oriented aliquot was prepared for each sample. Measurements were carried out at a rate of $2.0^{\circ}$ per minute from $3^{\circ}$ to $50^{\circ}$ using a $\mathrm{CuK} \alpha$ target $\mathrm{X}$-ray tube with an acceleration voltage of $40 \mathrm{kV}$ and filament current of $100 \mathrm{~mA}$. The abundances of minerals in the ash 


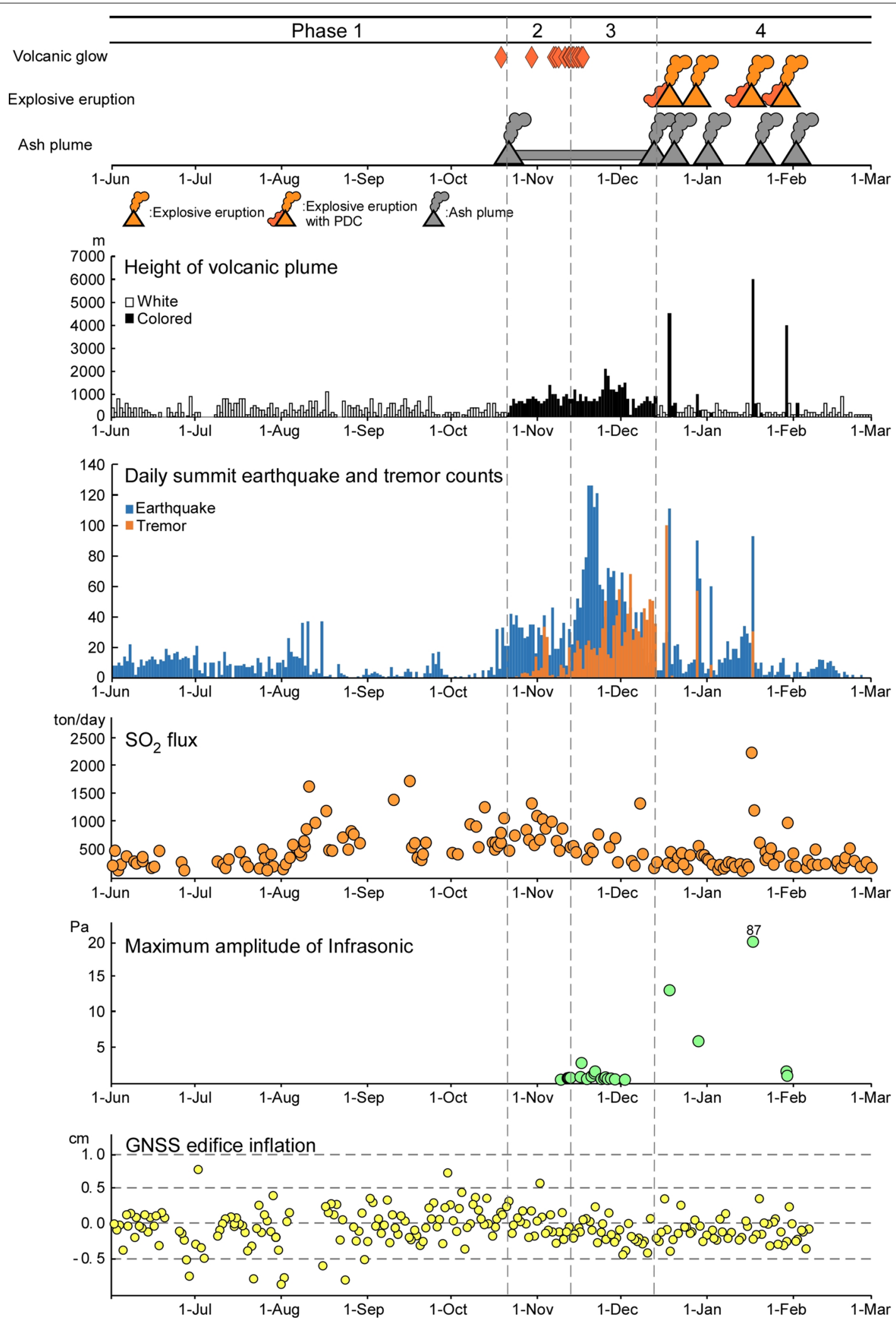

Fig. 2 Timeline of monitoring data for the 2018-2019 eruption of Kuchinoerabujima Volcano ( modified from Sugai et al., 2019) 


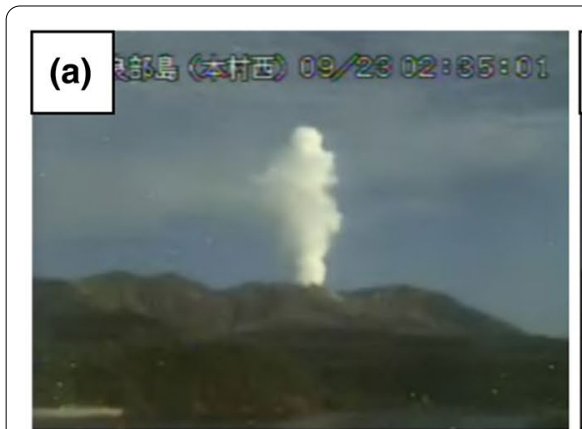

Sep. 23, 2018 (Phase 1)

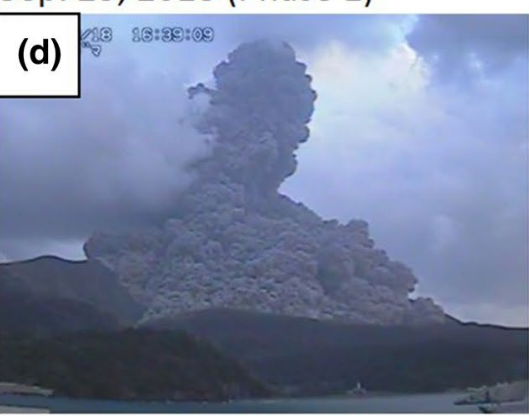

Dec. 18, 2018 (Phase4)

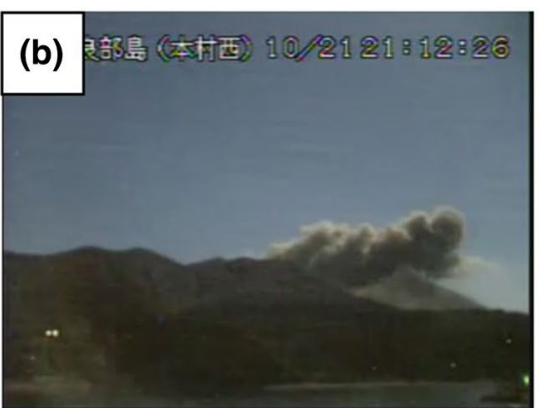

Oct. 21, 2018 (Phase 2)

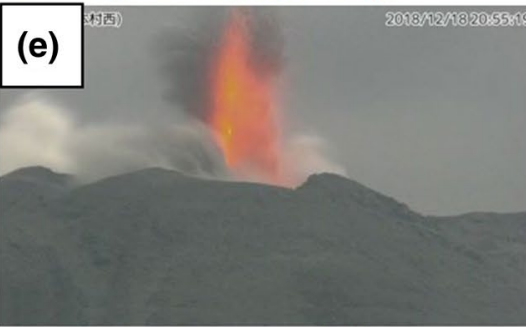

Dec. 18, 2018 (Phase4)

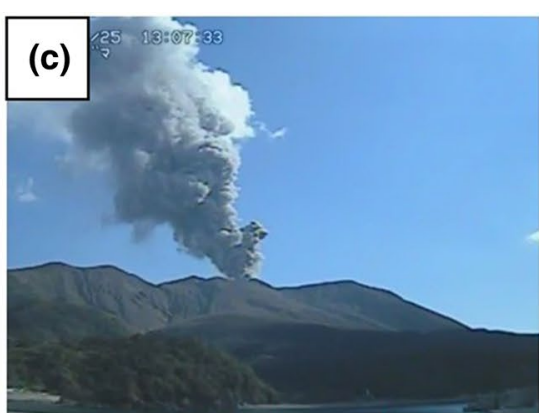

Nov. 25, 2018 (Phase 3)

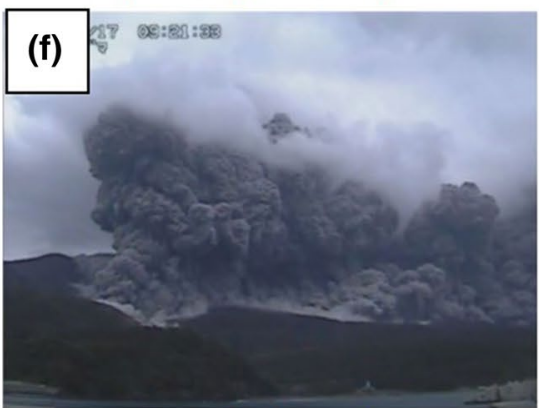

Jan. 17, 2019 (Phase4)

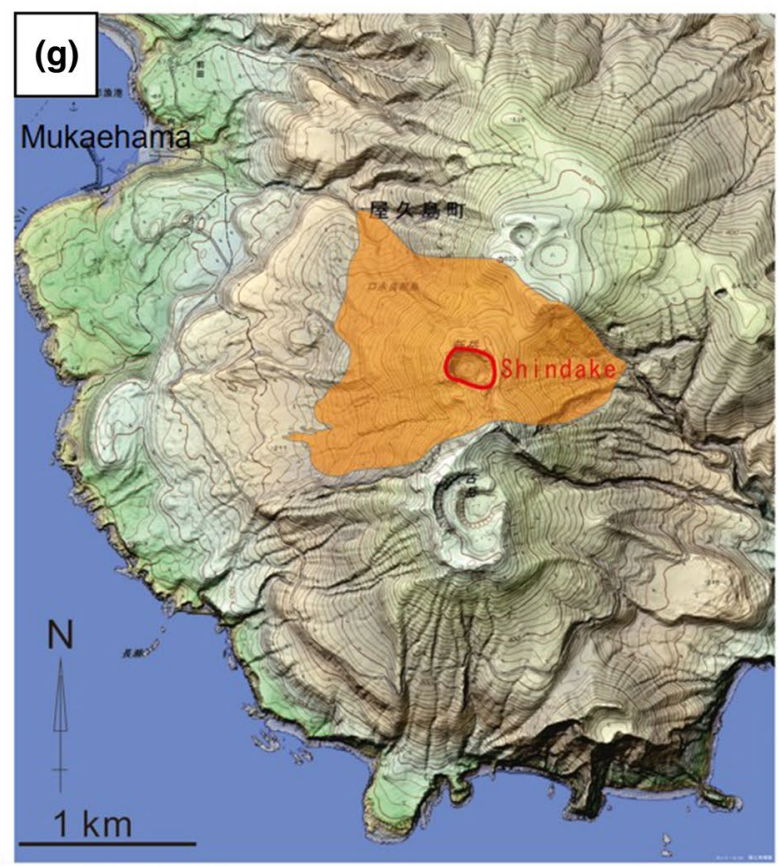

Dec. 18, 2018

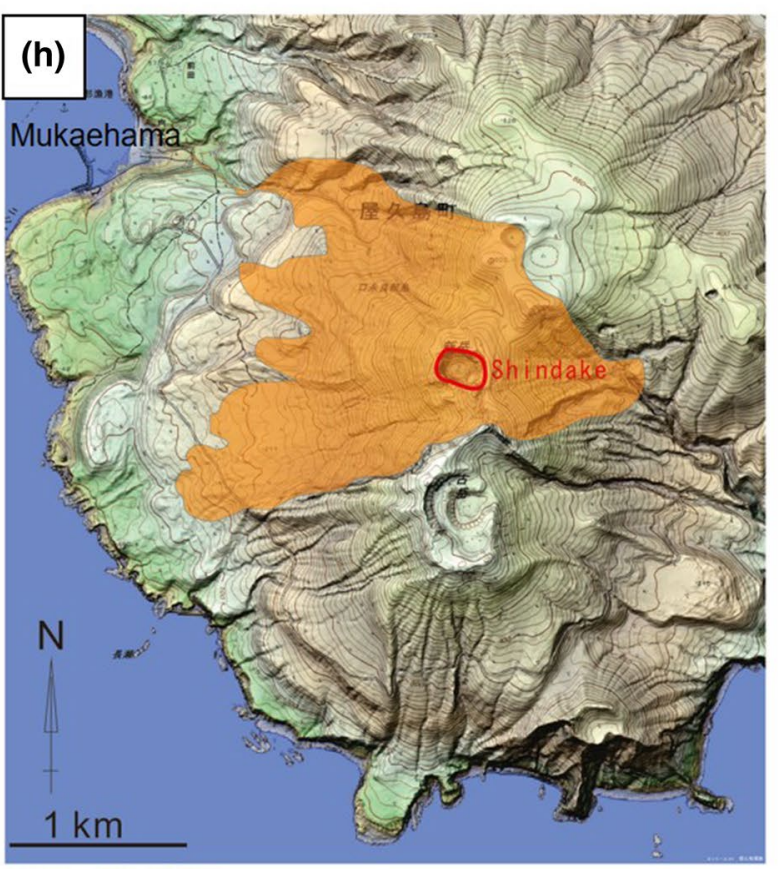

Jan. 17, 2019

Fig. 3 Snapshots of the volcanic plumes and PDCs from the monitoring camera located $3 \mathrm{~km}$ NW of Shindake operated by Japan Meteorological Agency A-F and distribution of PDCs $(\mathbf{G}, \mathbf{H})$. A White volcanic plume during Phase 1. B Colored volcanic plumes during Phase 2. C Colored volcanic plumes during Phase 3. D The explosive activity at 18 December 2018 (Phase 4). The front of the PDC can be recognized at the foot of the eruption column. E Volcanic glow observed by high-sensitivity monitoring camera during the night of 18 December 2018, after a PDC occurred (20:55'19" JST). F Second PDC occurred on 17 January 2019 (Phase 4). G, H Orange colored area indicates distribution of PDCs on 18 December 2018 G and 17 January 2019 (H) 
Table 1 Sample collection information

\begin{tabular}{|c|c|c|c|c|c|c|c|}
\hline \multirow[t]{2}{*}{ Sample ID } & \multirow[t]{2}{*}{ Date of eruption } & \multirow[t]{2}{*}{ Time of eruption onset } & \multirow[t]{2}{*}{ Comment } & \multicolumn{2}{|l|}{ Sampling time } & \multirow[t]{2}{*}{ Locality } & \multirow{2}{*}{$\begin{array}{l}\text { Direction } \\
\text { from the } \\
\text { crater }\end{array}$} \\
\hline & & & & From & To & & \\
\hline 18-Keb02-4 & Oct. 21, 2018 & $18: 31$ & & n.d & 23rd Oct. 17:30 & Nemachi & $\mathrm{NE}, 2 \mathrm{~km}$ \\
\hline 18-Keb03-1 & $\begin{array}{l}\text { Oct. 22, } 2018 \\
\text { Oct. } 25,2018\end{array}$ & $\begin{array}{l}\text { from } 15: 19, \text { Oct. } 22 \text { to } \\
\text { 15:21, Oct. } 25 ; \\
\text { from } 16: 21, \text { Oct. } 25 \text { to } \\
17: 30, \text { Dec. } 13,2018\end{array}$ & & Oct. 23rd 16:00 & 26th Oct. 13:16 & Tashiro & $\mathrm{NNW}, 3 \mathrm{~km}$ \\
\hline 18-Keb07-2 & Nov. 5, 2018 & $14: 20$ & & n.d & 5th Nov. 15:20 & Maeda & $\mathrm{NW}, 2.5 \mathrm{~km}$ \\
\hline 18-Keb09 & Nov. 12, 2018 & $\begin{array}{l}\text { 8:30-9:30 } \\
\text { (two explosions) }\end{array}$ & & 11th Nov & 12th Nov. $9: 40$ & Tashiro & NNW, $3 \mathrm{~km}$ \\
\hline 18-Keb12-1 & Nov. 20 and 21, 2018 & & & 20th Nov. 10:00 & 21st Nov. 14:10 & Honmura & $\mathrm{NW}, 3 \mathrm{~km}$ \\
\hline 18-Keb15 & Dec. 6, 2018 & & & 6th Dec. 10:00 & 6th Dec. 16:00 & Yumugi & $\mathrm{ENE}, 3 \mathrm{~km}$ \\
\hline 18-Keb17 & Dec. 18, 2018 & $16: 37$ & PDC & 18th Dec. 13:30 & 20th Dec. 8:30 & Tashiro & $\mathrm{NNW}, 3 \mathrm{~km}$ \\
\hline 18-Keb19-1 & Dec. 28, 2018 & 22:09 & & n.d & 29th Dec. 11:30 & $\begin{array}{l}\text { Nakama, } \\
\text { Yakushima- } \\
\text { cho }\end{array}$ & $\mathrm{SW}, 30 \mathrm{~km}$ \\
\hline 19-Keb03-3 & Jan. 17, 2019 & 9:19 & PDC & n.d & 18th Jan. 9:00 & Furudake & $\mathrm{SSE}, 2 \mathrm{~km}$ \\
\hline 19-Keb06 & Jan. 20, 2019 & $20: 51$ & & 18th Jan. ca. 8:00 & 22nd Jan. 14:30 & Nanakama & $\mathrm{SE}, 1.5 \mathrm{~km}$ \\
\hline 19-Keb09-2 & Jan. 29, 2019 & $17: 13$ & PDC & n.d & 30th Jan. 14:00 & Nanakama & $\mathrm{SE}, 1.5 \mathrm{~km}$ \\
\hline
\end{tabular}

were semi-quantitatively estimated based on peak intensities of the minerals. Mineral abundances in the ashes were estimated from the ratio of peak intensities of rock-forming mineral (plagioclase) versus those of silica minerals (quartz, cristobalite, and tridymite), sulfate minerals (gypsum, anhydrite, and alunite), and sulfide mineral (pyrite).

To estimate the contribution of volcanic gases and hydrothermal fluids, ash-leachates were analyzed based on the recommended method of Witham et al. (2005). Raw samples were extracted with Milli-Q-grade deionized water at a ratio of 1:50 (ash/ water in g). Then, the samples were shaken in an ultrasonic bath for $1 \mathrm{~h}$. After standing for about $2 \mathrm{~h}$, the supernatant was filtered through a $0.2-\mu \mathrm{m}$ membrane filter. The filtrate was measured for $\mathrm{F}, \mathrm{Cl}, \mathrm{SO}_{4}, \mathrm{Na}, \mathrm{NH}_{4}, \mathrm{~K}, \mathrm{Ca}$, and $\mathrm{Mg}$ concentrations using ion chromatography. The filtrate was measured for $\mathrm{F}, \mathrm{Cl}, \mathrm{SO} 4, \mathrm{Na}, \mathrm{NH} 4, \mathrm{~K}, \mathrm{Ca}$, and $\mathrm{Mg}$ concentrations using ion chromatography with one standard deviation errors of $\pm 5 \%$ or less.

Ash samples for the component analysis were washed in distilled water for a few minutes using an ultrasonic cleaner to remove adhering fine particles. After drying at $100{ }^{\circ} \mathrm{C}$, the particles were sieved into several classes of grain size using metal meshes. The particles $>125 \mu \mathrm{m}$ in diameter were observed by optical microscope. When a suitable amount of particles with sizes of 250-500 $\mu \mathrm{m}$ were obtained, they were used for observation instead. Ash particles were embedded in epoxy resin and polished to expose their interiors.
Component analysis of ash particles were conducted on the polished particles (approximately 80-200 particles for each sample) using elemental maps acquired by the micro X-ray fluorescence instrument (Bruker M4 TORNADO) at GSJ, AIST. Analytical conditions of the X-ray generator were set at $40-50 \mathrm{kV}$ of acceleration voltage and $600 \mathrm{~mA}$ tube current for detection of the $\mathrm{K} \alpha$ lines of elements ( $\mathrm{Al}, \mathrm{Si}, \mathrm{S}, \mathrm{K}, \mathrm{Ca}, \mathrm{Fe}$ ). Conditions for X-ray map acquisition were 2.00-10.00 s/pixel of dwell time, 1-5 cycles and $4 \mu \mathrm{m}$ step of stage shifting. For detailed classification based on the ash appearance and microtextures, observations of ash particles were conducted using an optical binocular microscope, optical digital microscope (KEYENCE VHX-2000) and scanning electron microscope (SEM; JEOL JSM-6610LV) at GSJ. The SEM was operated with an acceleration voltage of $15 \mathrm{kV}$.

\section{Results}

\section{Minerals in the ashes}

The XRD measurement identified minerals contained in the ashes such as silica minerals (quartz, cristobalite, and tridymite), sulfate minerals (gypsum, anhydrite, and alunite), sulfide mineral (pyrite), and plagioclase (Table 2). Peaks of any clay minerals such as kaoline group minerals, pyrophyllite, and muscovite were not detected. All ash samples show sharp peaks for cristobalite and plagioclase. Plagioclase and quartz are the only volcanic rockforming minerals identified in this study. However, the quartz are regarded as hydrothermal in origin because it is not contained in the lava and pyroclastic deposits of 
Table 2 Minerals in the volcanic ash of the 2018-2019 eruption at Kuchinoerabujima Volcano

\begin{tabular}{|c|c|c|c|c|c|c|c|c|c|c|c|c|}
\hline Sample ID & Date of eruption & $\mathrm{PI}$ & Qtz & Cri & Tri & Alu & Gyp & Anh & Pyr & Silica/PI & sulfate/PI & sulfide/PI \\
\hline 18-Keb02-4 & Oct. 21, 2018 & $* * *$ & * & $* * *$ & * & $* * \dagger$ & n.p & * & n.p & 0.5 & 0.2 & 0.0 \\
\hline 18-Keb03-1 & $\begin{array}{l}\text { Oct. 22, } 2018 \\
\text { Oct. 25, } 2019\end{array}$ & $* * *$ & * & $* * *$ & $*$ & $*^{\dagger}$ & n.p & $* * *$ & n.p & 1.0 & 0.7 & 0.1 \\
\hline 18-Keb07-2 & Nov. 5, 2018 & $* * *$ & n.p & $* * *$ & $*$ & $* * \dagger$ & n.p & $* *$ & n.p & 0.6 & 0.3 & 0.0 \\
\hline 18-Keb09 & Nov. 12, 2018 & $* * *$ & n.p & $* * *$ & * & $* *^{\dagger}$ & n.p & $*$ & n.p & 1.0 & 0.5 & 0.1 \\
\hline 18-Keb12-1 & Nov. 20 and 21, 2018 & $* * *$ & $*$ & $* * *$ & * & $*^{\dagger}$ & n.p & $*$ & n.p & 0.9 & 0.4 & 0.1 \\
\hline 18-Keb15 & Dec. 6, 2018 & $* * *$ & * & $* * *$ & * & $*$ & $* *$ & n.p & n.p & 1.1 & 0.6 & 0.1 \\
\hline 18-Keb17 & Dec. 18, 2018 & $* *$ & * & $* * *$ & $*$ & $* *$ & ** & $* * *$ & $*$ & 3.3 & 8.1 & 0.5 \\
\hline 18-Keb19-1 & Dec. 28, 2018 & $* * *$ & $*$ & $* * *$ & $* * *$ & $* *$ & * & $* * *$ & n.p & 1.4 & 0.7 & 0.1 \\
\hline 19-Keb03-3 & Jan. 17, 2019 & $* * *$ & n.p & $* * *$ & $* * *$ & $* *$ & $* * *$ & $* * *$ & $*$ & 2.0 & 6.1 & 0.4 \\
\hline 19-Keb06 & Jan. 20, 2019 & $* * *$ & $*$ & $* * *$ & $*$ & $* *$ & $* * *$ & $* * *$ & $* *$ & 1.9 & 9.0 & 0.5 \\
\hline 19-Keb09-2 & Jan. 29, 2019 & $* * *$ & n.p & $* * *$ & * & $* * *$ & $*$ & $* * *$ & n.p & 0.9 & 1.1 & 0.1 \\
\hline
\end{tabular}

The intensities of X-ray peaks in the XRD analysis are shown as: ${ }^{* *}$ Intense; **Weak; *Minor; and n.p. no peaks were determined

Mineral abbreviations; PI plagioclase including anorthite and albite, Trd tridymite, Crs cristobalite, Qtz quartz, Gp gypsum, Anh anhydrite, Alu alunite and natro-alunite (minamiite); and Py pyrite

The peak intensities of alunite basically used K-alunite and those with ${ }^{\dagger}$ are natro-alunite (minamiite)

Ratio of peak value refers to the total peak intensity of maximum peaks of silica minerals of tridymite, cristobalite, and quartz (silica/PI); sulfate of gypsum, anhydrite, and alunite (sulfate/PI); and sulfide of pyrite (sulfide/PI), divided by maximum peak intensity of plagioclase (PI), respectively

the Shindake volcanic edifice where the 2018-2019 eruption vent opened (Geshi and Kobayashi 2007).

Volcanic ashes of Phase 2 and 3 have similar mineral assemblages, including abundant plagioclase, cristobalite, and anhydrite (Table 2). The Phase 2 ashes contain minor amounts of alunite, whereas the Phase 3 ashes contain minor amounts of gypsum. The ratios of silica/Pl, sulfate/ $\mathrm{Pl}$ and sulfide/Pl are almost constant in Phase 2 and 3 (Fig. 4).

The mineral assemblage of the ashes varied during the Phase 4 activities (Table 2). The Phase 4 ashes contain plagioclase, quartz, cristobalite, alunite, anhydrite,

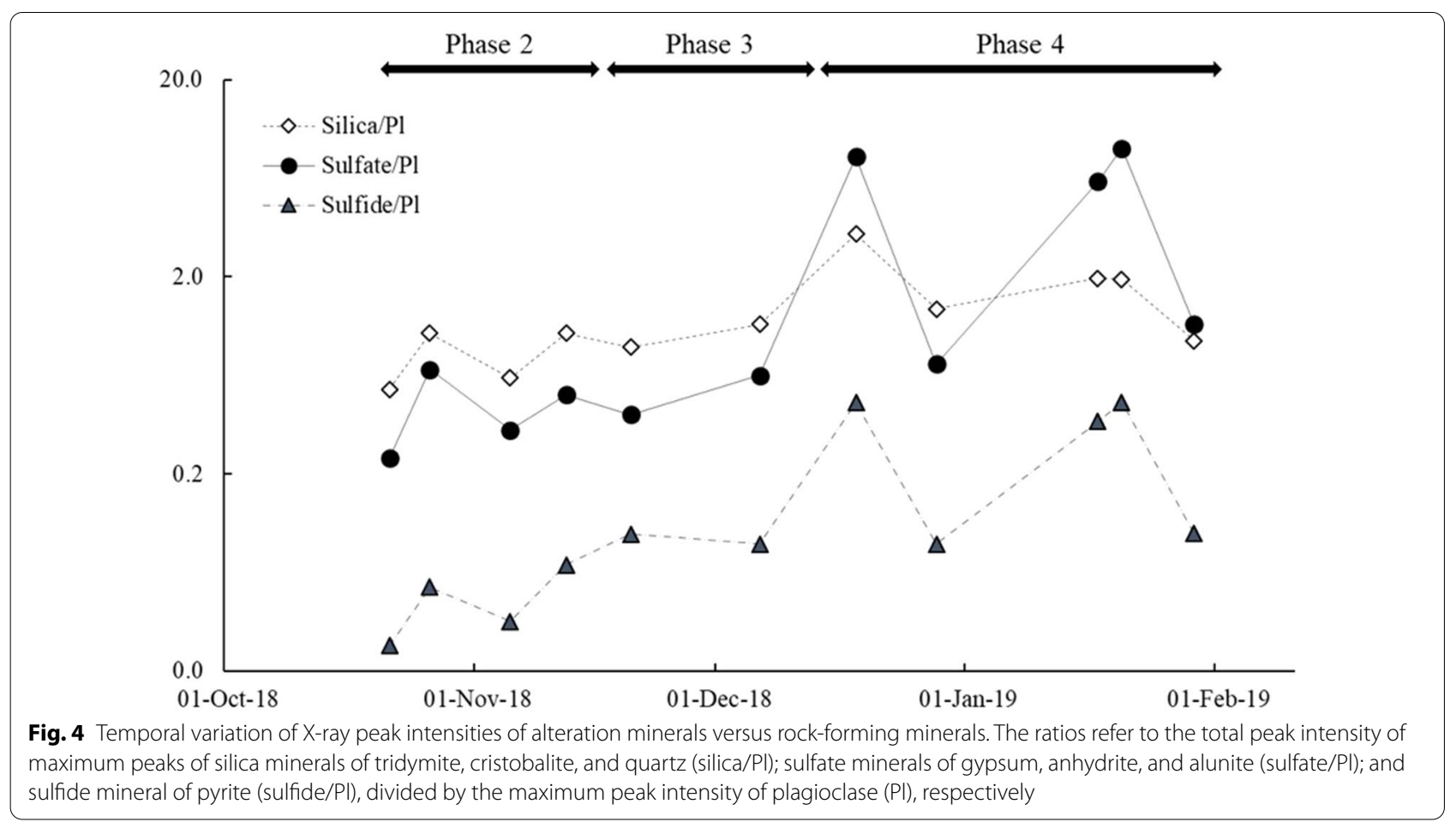


gypsum, and pyrite. X-ray peaks of plagioclase, anhydrite, and cristobalite are high and those of gypsum, quartz, tridymite, alunite, and pyrite are moderate to minor on average. The mineral assemblage of ashes of Phase 4 is characterized by the large abundance of anhydrite. In particular, the ashes of December 18 and January 17 show more intense X-ray peaks of anhydrite and sulfide than those of plagioclase. Therefore, the peak ratios of sulfate/ $\mathrm{Pl}$ and sulfide/Pl are higher than the others (Fig. 4).

\section{Ash-leachates}

Compositions of ash-leachates varied throughout the eruption sequence (Table 3). Concentrations of $\mathrm{SO}_{4}$ were low ( $<2$ wt.\%) in Phase 2 and 3, and increased in Phase 4 with the maximum concentration of 8 wt. \% (Fig. 5). In contrast, concentrations of $\mathrm{Cl}$ were almost constant during all phases (Table 3), and hence the $\mathrm{Cl} / \mathrm{SO}_{4}$ ratios shows inverse variation compared with the $\mathrm{SO}_{4}$ concentration (Fig. 5). Concentrations of $\mathrm{SO}_{4}$ and $\mathrm{Cl}$ of ashleachates commonly agree with those of $\mathrm{Ca}$ and $\mathrm{Na}+\mathrm{K}$, respectively, on a molal basis (Ossaka et al. 1998), indicating their occurrence in the form of $\mathrm{CaSO}_{4}$ and $(\mathrm{Na}+\mathrm{K}) /$ $\mathrm{Cl}$ on ashes. The $\mathrm{Ca} / \mathrm{SO}_{4}$ ratios are almost 1 in Phase 2 and 3, but decrease to 0.8 and 0.9 in Phase 4 (Fig. 5). In contrast, the ratio of $(\mathrm{Na}+\mathrm{K}) / \mathrm{Cl}$ are around 0.4 in Phase 2 , and increased to almost 1 in Phase 4 . These variations indicate that the origin of ash changed. The leachate composition of the ashes from the 2014 and 2015 eruptions of Kuchinoerabujuma Volcano are similar to those of Phase 4 ashes of 2018-2019 eruption (Table 3).

\section{Component analysis of the ash grains}

The collected ash samples are composed of non-altered rock fragments and variously altered particles (Table 4). To investigate the temporal variation of ash particle components, the ash particles were classified into a non-altered type (Type 1), a weakly altered type (Type 2) and five types of intensely altered particles (Type 3-1 to Type 3-5), based on X-ray intensity maps, optical microscope observations and SEM backscattered electron (BSE) images (Fig. 6). Fragments of crystals were also found in the ashes.

Ash particles showing no traces of alteration were classified as non-altered particles (Type 1; Fig. 6a). These particles commonly display a glassy luster, exhibit translucent gray-color to transparent dark-color with fine patches of opaque minerals, and have angular to sub-angular shapes. No particles with fluidal shapes were observed in the range from $250 \mu \mathrm{m}$ to coarser size (lapilli), which were rarely collected. Distinct signals of silicon, aluminum, and potassium were detected by X-ray map analysis. The particles have hyalopilitic or intersertal textures and consist of minor plagioclase phenocrysts and volcanic glass. The groundmass contains abundant microlites of plagioclase, pyroxenes, $\mathrm{Fe}-\mathrm{Ti}$ oxides and silica minerals. Vesicles are rarely recognized in the interstitial glass.

Partially altered particles (Type 2) are gray- to whitecolored translucent particles with sub-angular to angular shapes (Fig. 6b). Features of this type are similar to those of the non-altered particles under the microscope and elemental maps (Fig. 6). The particles are characterized by groundmass textures consisting of fine aggregates of anhedral silica minerals with minor clay minerals, unclear crystal boundaries for microlites and tabular to irregular voids. Original volcanic rock textures are replaced by silica minerals and minor hydrothermal clay mineral(s) as pseudomorphs, although the area of the hydrothermal clay mineral(s) in each particle was much less than those of intensely altered particles. The elemental association possibly indicates they contain zeolite group minerals and/or clay minerals such as Kaoline

Table 3 Water-soluble species on volcanic ash samples of the 2018-2019 eruption at Kuchinoerabujima Volcano

\begin{tabular}{|c|c|c|c|c|c|c|c|c|c|c|c|c|}
\hline Sample ID & Date of eruption & $F^{*}$ & $\mathrm{Cl}^{*}$ & $\mathrm{SO}_{4}^{*}$ & $\mathrm{Na}^{*}$ & $\mathrm{NH}_{4}^{*}$ & $\mathrm{~K}^{*}$ & $M g^{*}$ & $\mathrm{Ca}{ }^{*}$ & $\mathrm{Cl} / \mathrm{SO}_{4}{ }^{* *}$ & $(\mathrm{Na}+\mathrm{K}) / \mathrm{Cl}^{* *}$ & $\mathrm{Ca} / \mathrm{SO}_{4}{ }^{* *}$ \\
\hline 18-Keb02-4 & 21st Oct. 2018 & 354.2 & 2484.0 & 3566.5 & 584.3 & 7.1 & 80.3 & 98.0 & 2631.3 & 1.89 & 0.39 & 1.77 \\
\hline 18-Keb03-1 & 26th Oct. 2018 & 354.9 & 1719.3 & $19,684.7$ & 437.0 & 0.0 & 56.9 & 58.9 & 8529.4 & 0.24 & 0.42 & 1.04 \\
\hline 18-Keb07-2 & 5th Nov. 2018 & 325.7 & 1128.1 & $12,273.8$ & 315.4 & 0.0 & 43.6 & 45.0 & 5429.1 & 0.25 & 0.47 & 1.06 \\
\hline 18-Keb09 & 12th Nov. 2018 & 387.7 & 2021.8 & 8658.6 & 576.8 & 0.0 & 85.7 & 79.1 & 4469.4 & 0.63 & 0.48 & 1.24 \\
\hline 18-Keb12-1 & 20th Nov. 2018 & 244.8 & 570.4 & 7846.1 & 272.5 & 0.0 & 17.5 & 27.1 & 3309.1 & 0.20 & 0.76 & 1.01 \\
\hline 18-Keb15 & 6th Dec. 2018 & 479.8 & 2572.0 & $22,610.9$ & 479.3 & 0.0 & 81.4 & 90.9 & $10,036.3$ & 0.31 & 0.32 & 1.06 \\
\hline 18-Keb17 & 18th Dec. 2018 & 466.6 & 2315.0 & $79,124.1$ & 2135.3 & 16.5 & 120.6 & 479.6 & $29,034.2$ & 0.08 & 1.47 & 0.88 \\
\hline 18-Keb19-1 & 28th Dec. 2018 & 127.5 & 1815.9 & $29,738.1$ & 1099.9 & 0.0 & 183.7 & 416.7 & $10,845.4$ & 0.17 & 1.03 & 0.87 \\
\hline 19-Keb03-3 & 17th Jan. 2019 & 235.1 & 724.5 & $82,760.6$ & 434.7 & 0.0 & 85.4 & 381.3 & $29,152.4$ & 0.02 & 1.03 & 0.84 \\
\hline 19-Keb06 & 20th Jan. 2019 & 134.8 & 4725.5 & $55,724.3$ & 684.0 & 0.0 & 57.2 & 940.2 & $21,172.4$ & 0.23 & 0.23 & 0.91 \\
\hline 19-Keb09-2 & 29th Jan. 2019 & 57.8 & 1195.3 & $23,466.3$ & 850.1 & 0.0 & 93.5 & 352.9 & 7851.9 & 0.14 & 1.17 & 0.80 \\
\hline
\end{tabular}

*in $\mathrm{mg} / \mathrm{kg}$. **In molar ratio 


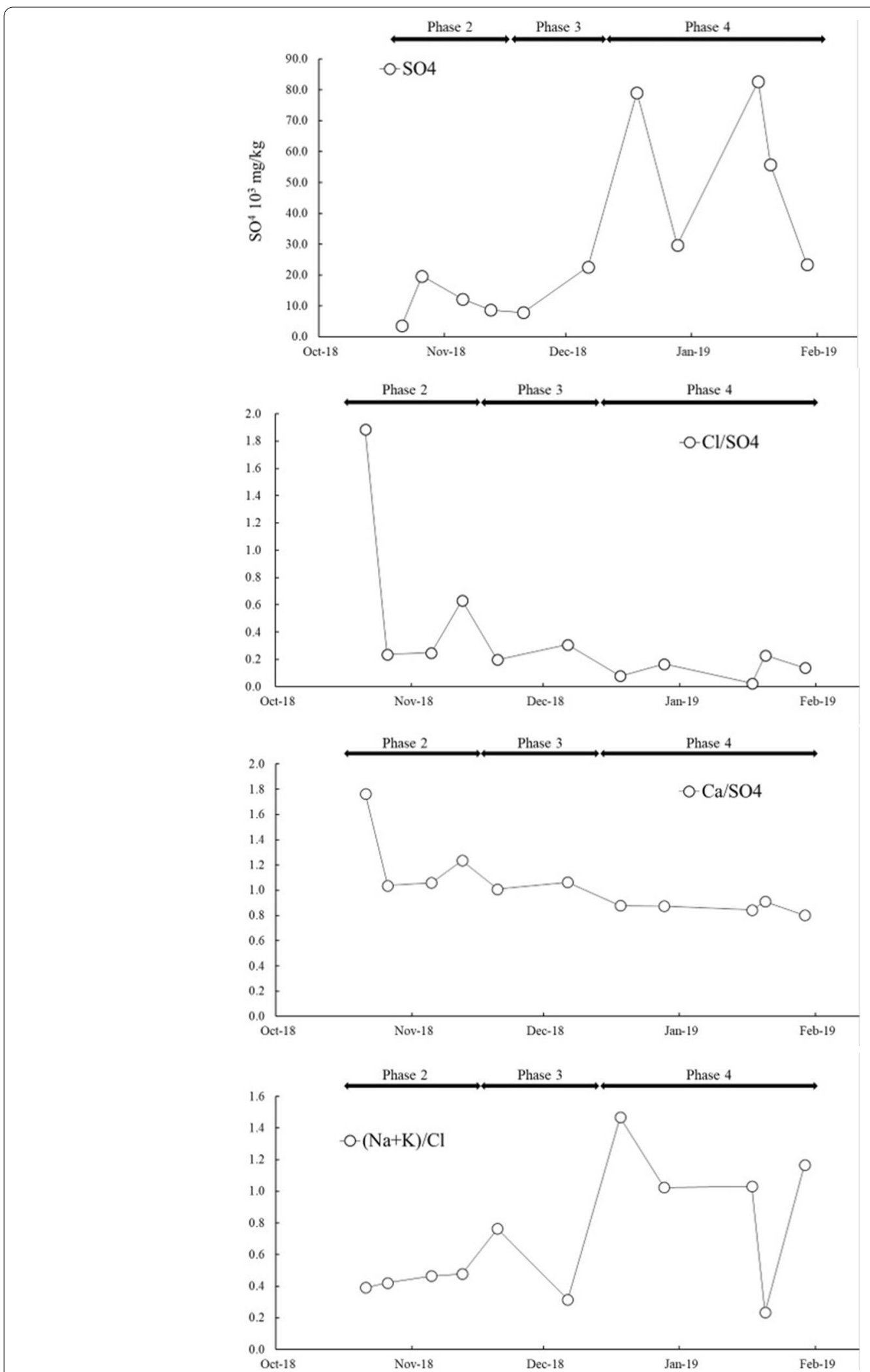

Fig. 5 Temporal variation of concentration and molar ratios of water-soluble species from the volcanic ash samples 
Table 4 Type classifications of volcanic ashes from the 2018-2019 eruption at Kuchinoerabujima Volcano

\begin{tabular}{|c|c|c|c|c|c|c|c|}
\hline \multirow{3}{*}{$\begin{array}{l}\text { Type } \\
\text { Sub-type }\end{array}$} & \multirow{3}{*}{$\begin{array}{l}\text { Type-1 } \\
\text { Non-altered }\end{array}$} & \multirow{4}{*}{$\begin{array}{l}\text { Type-2 } \\
\text { Partially altered }\end{array}$} & \multicolumn{5}{|l|}{ Type-3 } \\
\hline & & & \multicolumn{5}{|l|}{ Intensely altered } \\
\hline & & & Type 3-1 & Type 3-2 & Type 3-3 & Type 3-4 & Type 3-5 \\
\hline \multicolumn{2}{|l|}{ Name of particle } & & Silica & Sulfate & Sulfide & Sulfur-bearing & Others \\
\hline Optical discription & $\begin{array}{l}\text {-Glassy luster, } \\
\text { translucent gray- } \\
\text { color to transpar- } \\
\text { ent dark-color } \\
\text { particles } \\
\text { Angular to sub- } \\
\text { angular shape }\end{array}$ & $\begin{array}{l}\text { Translucent gray- } \\
\text { to white-color } \\
\text { particles } \\
\text { Angular to sub- } \\
\text { angular shapes }\end{array}$ & \multicolumn{4}{|c|}{$\begin{array}{l}\text { White-, yellowish brown-, or dark-colored particles } \\
\text { Angular to rounded shapes }\end{array}$} & \\
\hline $\begin{array}{l}\text { X-ray map } \\
\text { (intense elements) }\end{array}$ & $\mathrm{Si}, \mathrm{Al}, \mathrm{K}$ & $\mathrm{Si}, \mathrm{Al}, \mathrm{K}$ & $\mathrm{Si}$ & $\mathrm{S}, \mathrm{Ca}$ & $\mathrm{S}, \mathrm{Fe}$ & S & $\mathrm{Al}, \mathrm{K}, \mathrm{Ca}$ \\
\hline \multirow[t]{2}{*}{$\begin{array}{l}\text { Minerals con- } \\
\text { tained }\end{array}$} & $\cdots$ & $\cdots$ & $\underline{\text { Silica mineral(s) }}$ & $\underline{\text { Sulfate mineral(s) }}$ & $\underline{\text { Sulfide mineral }}$ & $\underline{\underline{\text { Sulfur-bearing }}}$ & \multirow{2}{*}{$\begin{array}{l}\text { zeolite } \\
\text { group } \\
\text { minerals? } \\
\text { clay min- } \\
\text { erals? }\end{array}$} \\
\hline & $\cdots$ & $\cdots$ & Qz, Cri, Tri & Gyp, Anh, Alu & Pyr & Gyp, Anh & \\
\hline $\begin{array}{l}\text { Textural descrip- } \\
\text { tion }\end{array}$ & $\begin{array}{l}\text {-no traces of } \\
\text { alteration }\end{array}$ & $\begin{array}{l}\text { Groundmass: } \\
\text { consisting of } \\
\text { fine aggregate } \\
\text { of anhedral silica } \\
\text { minerals, unclear } \\
\text { crystal boundary } \\
\text { of microlite and } \\
\text { tabular to irregular } \\
\text { voids } \\
\text { Original volcanic } \\
\text { rock textures } \\
\text { are replaced to } \\
\text { silica minerals and } \\
\text { minor hydrother- } \\
\text { mal clay mineral(s) }\end{array}$ & $\cdots$ & $\begin{array}{l}\text { [Type } \mathbf{3 - 2 C} \text { ] } \\
\text { An aggregate of } \\
\text { coarse euhedral } \\
\text { sulfate crystals } \\
\text { [Type } \mathbf{3 - 2 F} \text { ] } \\
\text { Euhedral sulfate } \\
\text { crystals included } \\
\text { in the aggregate } \\
\text { of fine silica and } \\
\text { clay minerals }\end{array}$ & $\begin{array}{l}\text { Mainly pyrite and } \\
\text { sulfate minerals } \\
\text { with minor silica } \\
\text { and clay minerals }\end{array}$ & $\begin{array}{l}\text { Minor but com- } \\
\text { monly contain } \\
\text { gypsum and/or } \\
\text { anhydrite crystals }\end{array}$ & \\
\hline
\end{tabular}

group minerals, pyrophyllite, and muscovite, but these minerals were not detected by XRD likely due to their low contents. This silica mineral with dominant vugs is considered as the "residual vuggy silica" which is a typical texture of hydrothermally altered rocks (Stoffregen 1987; Sillitoe 2010; Delmelle et al. 2015).

Intensely altered particles (Type 3 ) show various visual features of white-, yellowish brown-, or dark-colored angular to rounded particles. Intensely altered particles can be subdivided into five subclasses based on their dominant elements as: silicon (Type 3-1), sulfur and calcium (Type 3-2), sulfur and iron (Type 3-3), sulfur (Type 3-4), and others (Type 3-5). When a particle showed heterogeneity in the composition, the particle was classified based on feature of the dominant area. Based on the combination of SEM-EDS and XRD results, these subclasses were identified as: silica minerals (quartz, cristobalite, and tridymite: Type 3-1). sulfate minerals (gypsum, anhydrite, and alunite: Type 3-2); sulfide (pyrite: Type 3-3), fine aggregates of sulfur-bearing minerals (Type 3-4); and others (Type 3-5).
Type 3-1 particles are fine-grained silica minerals with minor plagioclase and clay minerals (Fig. 6c). They are characterized by pseudomorphs with complete replacement of the original phenocrysts of volcanic rockforming minerals by silica minerals, and by groundmass textures consisting of fine aggregates of anhedral silica minerals, unclear crystal boundaries for microlites, and tabular to irregular voids. These features are considered to represent the typical residual vuggy texture of hydrothermally altered rocks (Stoffregen 1987; Sillitoe 2010; Delmelle et al. 2015). Some Type 3-1 particles are coated by fine aggregates of sulfate and/or sulfide minerals on the surface. Vugs in those particles are often filled by the same materials. The sulfate mineral particles (Type 3-2) typically appear as an aggregate of coarse euhedral sulfate crystals (> $100 \mu \mathrm{m}$ : Type 3-2C; Fig. 6d and Fig. 7c, d) or fine euhedral sulfate crystals $(<50 \mu \mathrm{m}$ : Type $3-2 \mathrm{~F}$; Fig. $7 \mathrm{~g}$ and f). Type $3-2 \mathrm{~F}$ particles are accompanied by aggregates of fine silica and clay minerals. The sulfide particles (Type 3-3) have a matrix consisting mainly of fine pyrite $(>\sim 10 \mu \mathrm{m})$ and sulfate minerals with minor silica and 


\section{Type 1: Non-altered particle}

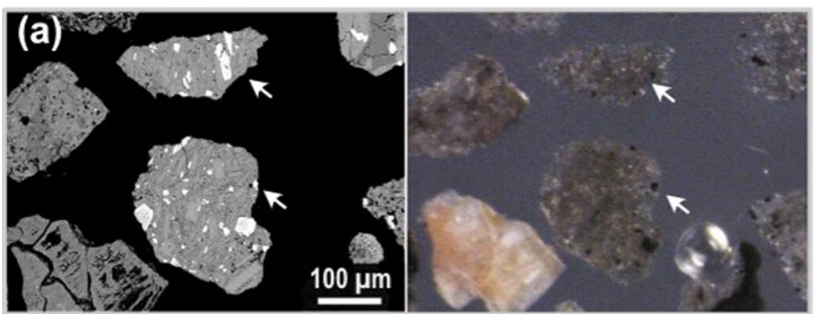

\section{Type 3: Intensly altered particle}

Type 3-1: Silica particle

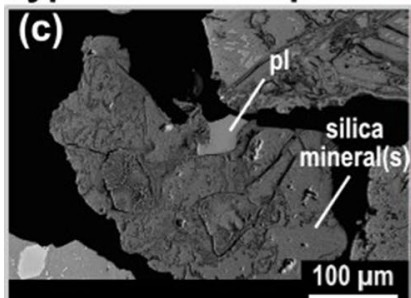

Type 3-3: Sulfide particle

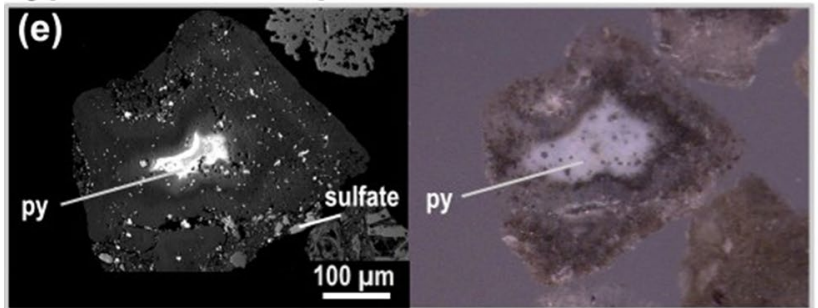

\section{Type 3-5: Others}
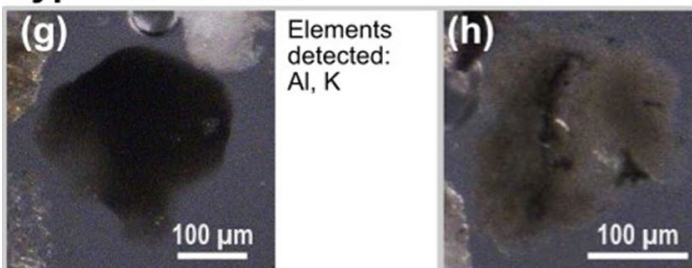
$\mathrm{Al}, \mathrm{K}$

\section{Type 2: Partially altered particle}

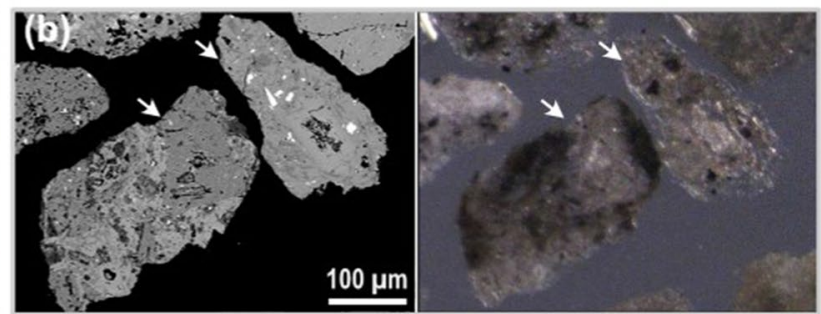

Type 3-2C: Sulfate particle (Coarse)

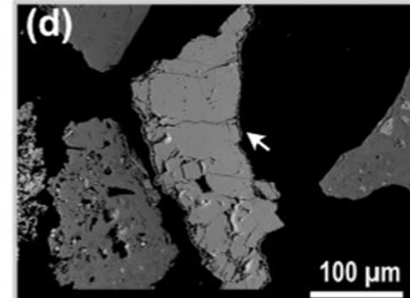

Type 3-4: Sulfur-bearing particle
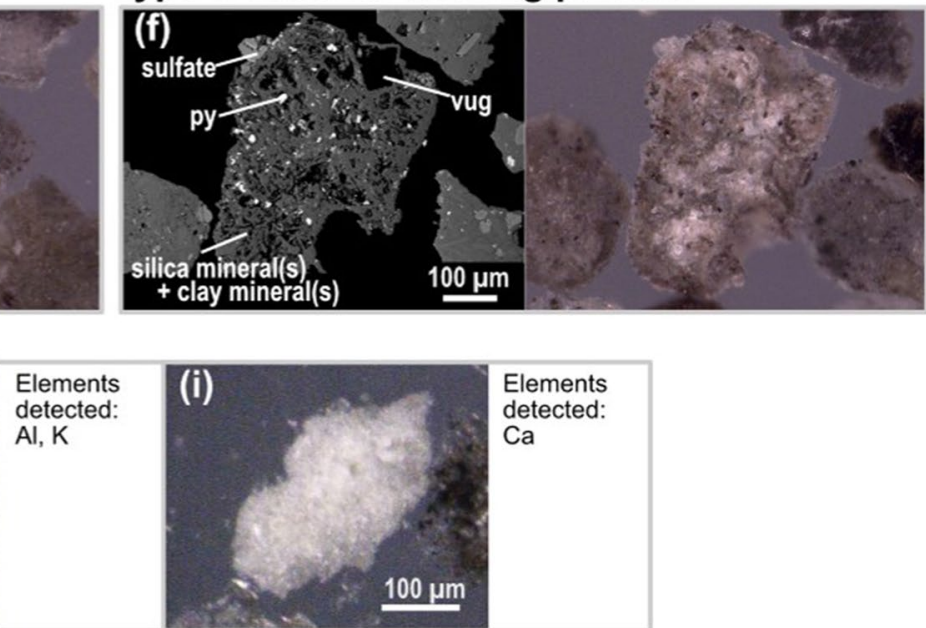

Elements

Fig. 6 Representative images of classified ash particles as backscattered electron images and optical digital microscope images. Arrows in a, b and $d$ indicate the particles classified in each category. Sulfate, alunite and simple sulfate minerals such as anhydrite and gypsum; $p y$ pyrite, $p /$ plagioclase

clay minerals (Fig. 6e). Fine aggregates of sulfur-bearing particles (Type 3-4) commonly contain minor amounts of gypsum and/or fine anhydrite crystals (Fig. 6f). Type 3-5 particles contain calcium, potassium and aluminum and show variable features under microscopic observation, and SEM-EDS analysis (Fig. 6g-i). In addition to these observations, many Type 2 and Type 3 particles from Phase 4 show red coloration. Approximately 5 to $15 \%$ of particles from Phase 4 show red coloration, in contrast to the red particles in Phase 2 and 3 which were less than $1 \%$. The color was recognized on particle surfaces and on opaque minerals.

\section{Temporal variations of volcanic ejecta}

The presence of non-altered particles (Type 1) is a critical characteristic of the volcanic ashes of Phase 2 and 3 activities (Fig. 8). The volcanic ashes mainly contain nonaltered particles and partially altered particles (Type 2). Proportions of the aggregates of euhedral sulfate particles (Type 3-2) and silicic alteration particles (Type 3-1) are less than $10 \%$ and $30 \%$, respectively. All the Type 3-2 particles were the aggregates of coarse euhedral sulfate (Type 3-2C; Fig. 7 a-d). The Phase 2 and 3 ashes are abundant in plagioclase with moderate to minor cristobalite, anhydrite, gypsum, and alunite (Table 2). The abundance of 


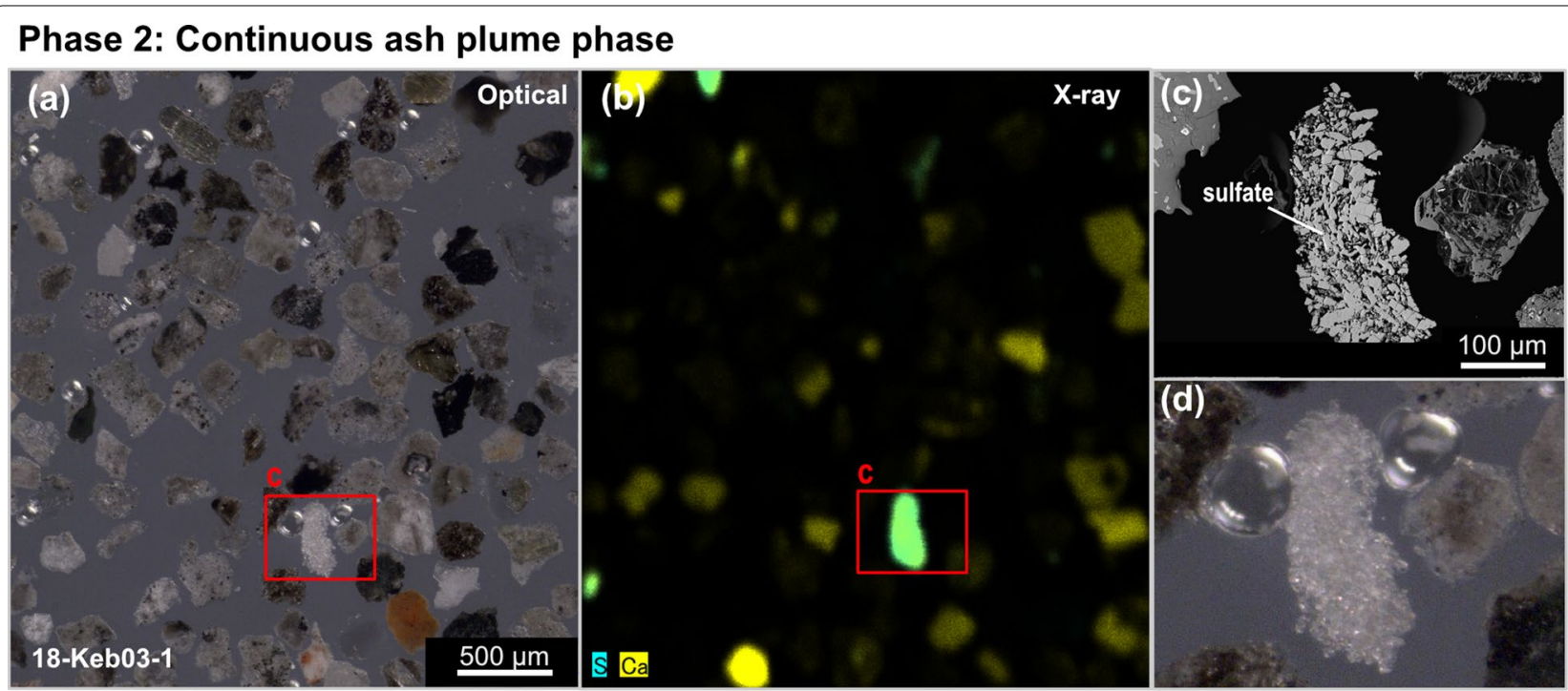

Phase 4: Explosive eruptions phase

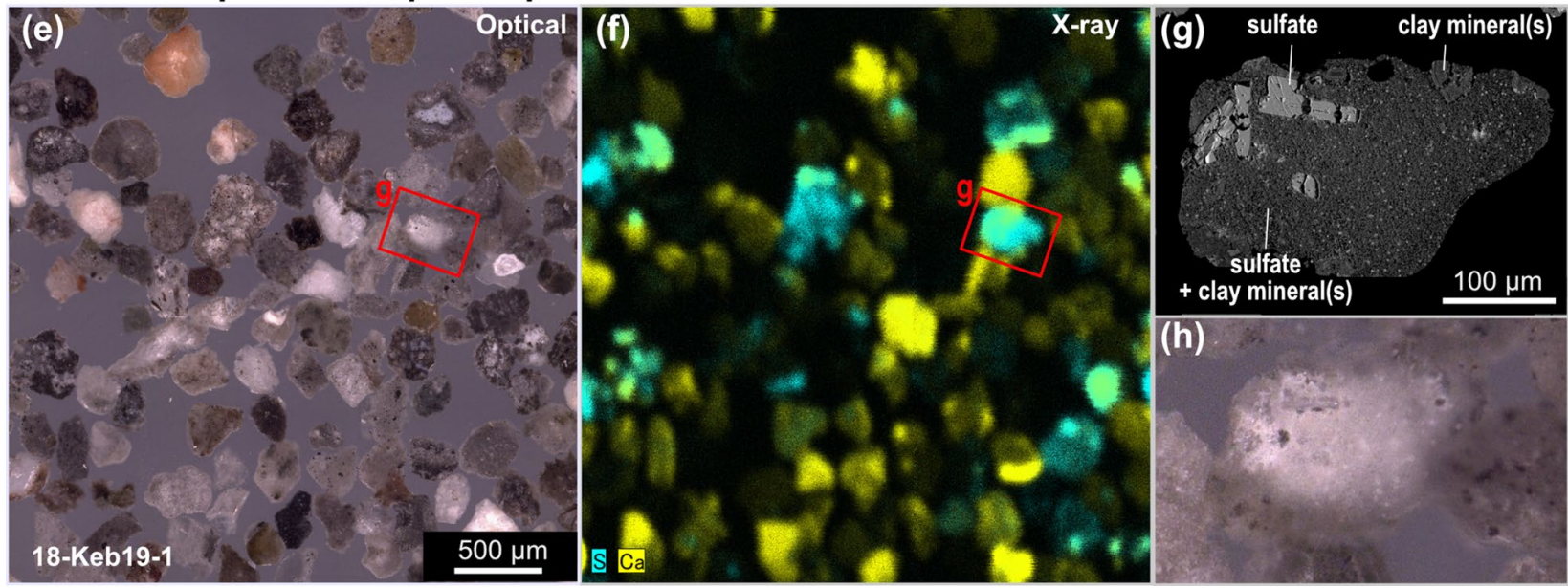

Fig. 7 Representative ash samples from Phase $2(\mathbf{a}-\mathbf{d})$ and Phase $4(\mathbf{e}-\mathbf{h})$ indicated by optical $(\mathbf{a}, \mathbf{d}, \mathbf{e}, \mathbf{h})$, X-ray $(\mathbf{b}$ and $\mathbf{f})$ and backscattered electron (c and $\mathbf{g}$ ) images. c, d A coarse euhedral sulfate crystal typical in Phase 2. g, h A fine euhedral sulfate crystals typical in Phase 4

plagioclase indicates that the Phase 2 and 3 ashes mainly consist of fresh volcanic rock in accordance with the nonaltered and partially altered particles-dominant mineral assemblages (Fig. 4 and Table 2). High values of $\mathrm{Cl} / \mathrm{SO}_{4}$ (1.9-2.0) for the ash-leachates were measured for the ashes from the earliest eruption and these results agree with the low proportion of water-soluble sulfate minerals (gypsum and anhydrite; Table 2 and Fig. 4).

Proportions of the particle types changed markedly in Phase 4 (Fig. 8). Proportions of non-altered particles (Type 1) decreased to less than $2 \%$ with the exception of the volcanic ash of December 28. In contrast, the total proportion of sulfur-bearing, intensely altered particles (Type 3-2, 3-3 and 3-4) increased to $20-50 \%$. The proportion of silicic altered particles (Type 3-1) are less than $20 \%$ which did not change from through Phase 2 and 3 . The proportion of weakly altered particles (Type 2) decreased to $30-50 \%$. The intensely altered particles of Type 3-2 Type 3-3 and Type 3-4 are dominant particle types in Phase 4. In contrast to those in Phase 2 and 3, almost all the Type 3-2 particles in this phase were the aggregates of fine euhedral sulfate (Type 3-2F; Fig. 7e-h). Sulfide-dominant particles (Type 3-3) and sulfur-bearing particles (Type 3-4) also increased from late Phase 3 (December 6, 2018) to Phase 4 (Fig. 8). The increase of these particles indicates that sulfide (pyrite) crystallization became dominant. During the same period, fine sulfate crystals (Type 3-2) also increased in abundance. The volcanic ashes of Phase 4 have sulfate and silica dominant mineral assemblages and high concentrations of $\mathrm{SO}_{4}$ and 


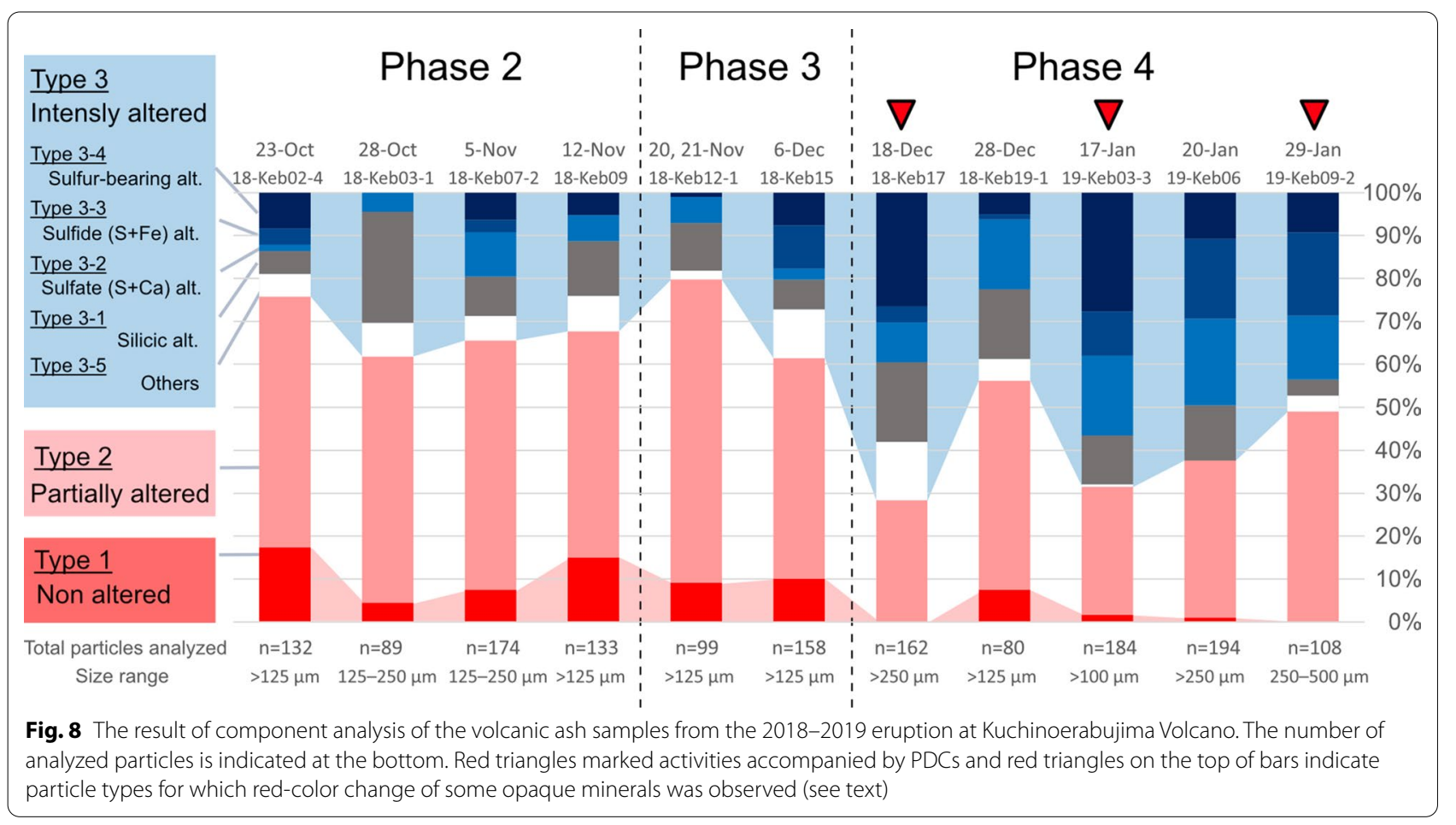

low levels of $\mathrm{Cl} / \mathrm{SO}_{4}$ for the ash-leachates, indicating that these ashes contain abundant water-soluble sulfate minerals (Figs. 4 and 5). These results agree with the high proportion of intensely altered particles and low proportion of non-altered particles (Fig. 8). The volcanic ash of the eruption on December 28 is an exception of Phase 4 activity. They contain nearly $10 \%$ of non-altered particles and have a plagioclase-dominant mineral assemblage (Figs. 4 and 8).

\section{Discussion}

\section{Origin of ash particles}

Volcanic ash from the 2018-2019 eruption at Kuchinoerabujima Volcano consists of various particle types, which vary in abundance throughout the eruptive phases, suggesting changes in the particle origins. In this section, we discuss the origins of each particle type and their relationship to the eruptive phases.

The non-altered ash particles (Type 1) are characterized by abundant plagioclase, pyroxene, $\mathrm{Fe}-\mathrm{Ti}$ oxides with minor plagioclase phenocrysts. Groundmass textures are commonly hyalopilitic or intersertal (Fig. 6). The vitric, blocky, and poorly vesiculated features of the non-altered particles agree with the general features of vulcanian eruption products (Morrissey and Mastin 2000) and are similar to juvenile materials of the 2014-2015 eruption at Kuchinoerabujima Volcano (Geshi et al. 2016). Although continuous ash emission is not common for vulcanian eruptions, the 2014-2015 eruption at Kuchinoerabujima Volcano and some andesitic stratovolcanoes have exhibited such eruption behavior (Kuchinoerabujima Volcano: Geshi et al. 2016; Sakurajima Volcano: Matsumoto et al. 2013; Aso Volcano: Ono et al. 1995; Kirishima Volcano: Miyabuchi et al. 2013). These features suggest that the non-altered ash particles originated from a newly intruded magma during or prior to the 2018-2019 eruption. The blocky shape and lack of obvious pumice and particles with fluidal form suggest that the non-altered particles were derived from a partially solidified magma.

Partially altered particles (Type 2) whose alteration textures were recognized only in groundmass, were possibly derived from the volcanic edifice or the newly intruded magma batch, because they also exhibit hyalopilitic or intersertal textures which are similar to the non-altered particles (Fig. 6). The alterations characterized by vuggy silica and crystallization of silica minerals in the groundmass indicate selective alteration of low resistance groundmass. These selective alteration textures suggest that reaction between original volcanic rock and hydrothermal fluids was short enough to leave microlites and phenocrysts unaltered. Observed alteration minerals were mostly silica minerals while clay minerals were minor. This mineral assemblage corresponds to the "residual silica zone" which indicates alteration by hydrothermal fluids with a strong acidity (Stoffregen 1987; Nogami and Yoshida 1993; Hedenquist et al. 2000; 
Sillitoe 2010). Therefore, the alteration of the partially altered particles was mainly caused by cation leaching with strongly acidic hydrothermal fluids for a short period.

Silica minerals-dominant intensely altered particles (Type 3-1) have a similar groundmass texture with the partly altered particles. Type 3-1 particles are characterized by pseudomorphic silica minerals and abundant vugs. These features indicate a sustained leaching by strongly acidic hydrothermal fluids, and correspond to features of the "residual silica zone", which is a common alteration type in a volcanic-hydrothermal system (Sillitoe 2010). This evidence indicates that Type 3-1 particles are derived from a hydrothermally altered zone (residual silica zone) formed prior to the 2018-2019 eruptive activity or recycled from previous eruption products (Houghton and Smith 1993; Graettinger et al. 2016).

Type 3-2 particles consist of abundant sulfate minerals (Fig. 6d), sometimes with minor amounts of clay minerals (Fig. 7). The dominance of sulfate minerals indicates alteration by sulfate-acid hydrothermal fluids (Reed 1997) such as under the conditions of an "advanced argillic alteration zone" which commonly contains clay minerals of kaolinite and pyrophyllite (Sillitoe 2010). Minor amounts of clay minerals in Type 3-2, however, do not agree with this feature. On the other hand, Type 3-2C particles are commonly observed during Phase 2 and 3 , when alunite and anhydrite are the dominant sulfate minerals. The coarse euhedral shapes indicate that these sulfate crystals freely grew in sulfate-saturated hydrothermal fluids (Christenson et al. 2010; Inguaggiato et al. 2018; van Hinsberg et al. 2021). On the other hand, the fine sulfate crystals (Type 3-2F) suggest a high nucleation rate indicating that Type $3-2 \mathrm{~F}$ particles formed under a higher supersaturation degree than that for Type 3-2C (Otálora and García-Ruiz 2014). The high degree of supersaturation for Type 3-2F was likely achieved by a rapid evaporation of sulfate-acid hydrothermal fluids. Therefore, Type 3-2F particles were directly derived from sulfate-saturated hydrothermal fluid before the development of an advanced argillic alteration zone. Additionally, this textural characteristic indicates that the features of particles were changed, and these particles were not derived from "clast recycling" (Houghton and Smith 1993; Graettinger et al. 2016).

The matrix of Type 3-3 particles consists of fine pyrite and sulfate minerals with minor silica and clay minerals (Fig. 6). This assemblage is similar to Type 3-1 particles, which are dominated by silica minerals and accompanying sulfide minerals in vugs, on the rims of particles, and on crystal boundaries between silica and clay minerals in the groundmass. These cutting relations indicate that sulfide crystallization followed silicification alteration, which suggests that Type 3-3 particles are formed by accretion of Type 3-1 particles with sulfide precipitation.

Type-3-4 particles commonly appear as silica minerals with abundant vuggy altered materials coated with fine aggregates of sulfur-bearing minerals (Fig. 6f). The texture of Type 3-4 particles is similar to Type 3-1 particles. The precipitation of sulfate and sulfide minerals in vugs and on the surface of the particles indicates that the sulfate and sulfide mineral crystallization followed the silicic alteration.

Type 3-5 particles possibly contain clay minerals (Fig. 6g-i), albeit in notably low amounts (Tables 2 and 4 ), when compared with the products of phreatic or phreatomagmatic eruptions from sub-volcanic hydrothermal systems that commonly contain abundant clay minerals (e.g., Christenson et al. 2010; Ohba 2011; Minami et al. 2016). The low proportion of these clay minerals may indicate the absence of a mature hydrothermal alteration zone around the conduit and that the volcanic ashes were mainly derived from an immature altered zone such as a partly altered magma batch.

\section{Eruptive sequence of the Kuchinoerabujima 2018-2019 eruption}

In the following section, we discuss the correlations between volcanic ash componentry and the monitoring data throughout the eruption sequence (Fig. 2). From July to the middle of October 2018 (Phase 1), $\mathrm{SO}_{2}$ flux increased, and edifice inflation had gradually progressed. These monitoring data may imply that magma was ascending to a shallow level at that time. Phase 1 can be interpreted as a precursory phase of the 2018-2019 eruption (Fig. 9).

Absence of a hydrothermal system beneath the crater during Phase 2 is suggested based on the following reasons. Regular but low-volume ash emission during Phase 2 implies minimal or no interaction between magma and a hydrothermal system. Observation of the glowing crater in Phase 2 indicates a high temperature for the vent. The low proportion of ash particles derived from hydrothermal fluids (Type 3-2F), and the high proportion of ash particles derived from the intruding magma batch (Type 1 and 2) and the pre-existing hydrothermally altered zone (Type $3-1$ and $3-2 \mathrm{C}$ ) imply that there was minimal or no interaction with a hydrothermal system (Fig. 9). Lesser abundance of water-soluble sulfate in Phase 2 indicates the absence of a dense fluid phase and implies the lack of a hydrothermal system (Figs. 4, 5, and 9). Phase 2 activity was characterized by almost continuous ash emission (Fig. 2). The dominance of non-altered and partially altered particles (Type 1 and Type 2; Fig. 6), high flux of $\mathrm{SO}_{2}$ gas (>500 t/day; Fig. 2), and the presence of a volcanic 


\section{Phase 1}

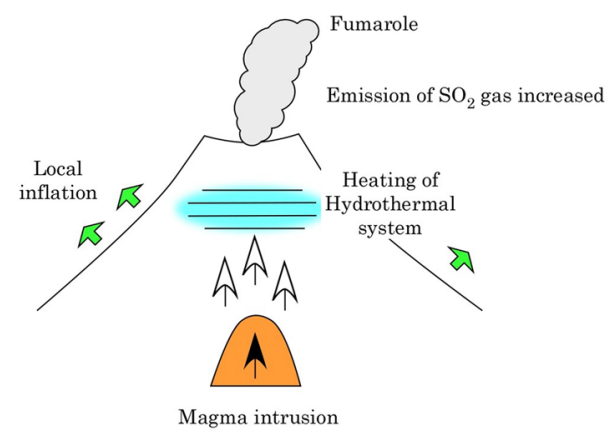

Phase 2

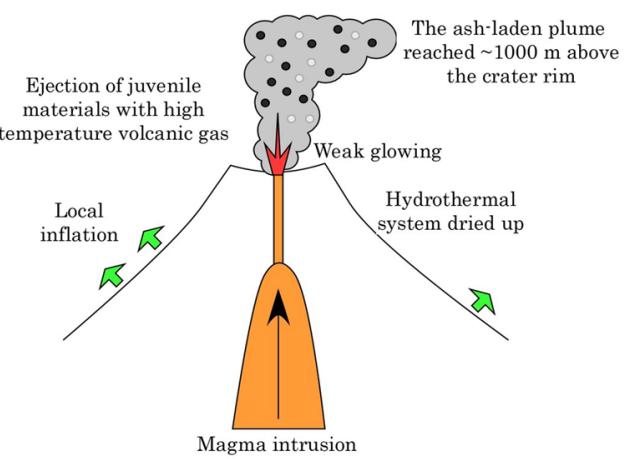

Phase 3

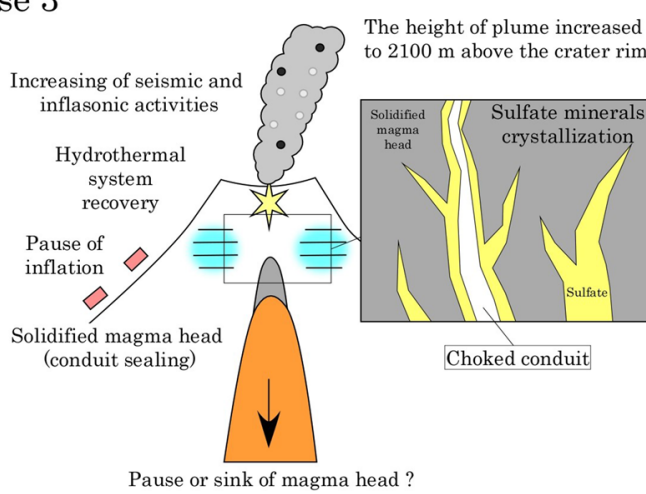

Phase 4

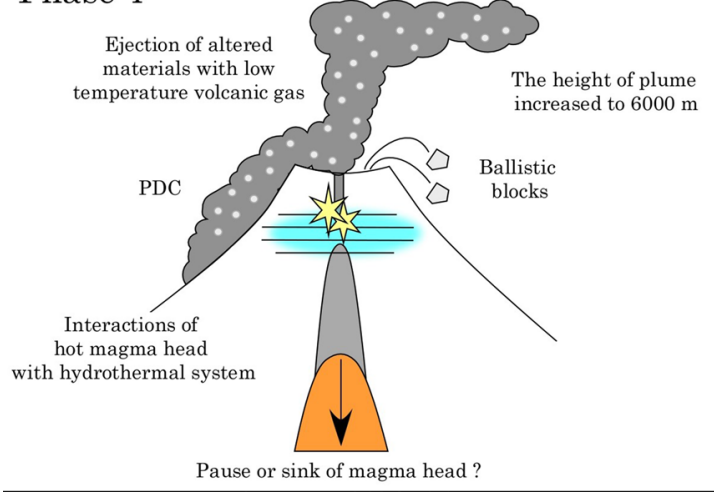

Fig. 9 Schematic illustrations showing the sequence of the 2018-2019 eruption at Kuchinoerabujima Volcano. Shallow ascending magma dried up a hydrothermal system beneath the eruption vent (Phase 1). Magmatic eruption occurred during Phase 2. The eruption products contain juvenile (dark circle) and altered materials (white). Continuous ash emission and weak glowing from the crater suggested a sufficiently high temperature for the crater. Edifice inflation paused in Phase 3. Hydrothermal fluid recovered in the shallow edifice. Precipitation of sulfate minerals choked the conduit. Explosive activities with PDCs occurred during Phase 4 due to interaction between magma and hydrothermal fluid

glow indicate that ascending magma drove the eruptive behavior during Phase 2 (Fig. 9). Altered particles collected during Phase 2 are primarily Type $3-1$ and Type $3-2 \mathrm{C}$, suggesting that most of the altered materials were derived from the shallow part of a pre-existing hydrothermal alteration zone. During the continuous ash emission and volcanic glow, a stable hydrothermal system cannot exist and the coarse euhedral sulfate needs to be derived from a pre-existing hydrothermal altered zone. Therefore, the volcanic activities of Phase 2 can be interpreted as magmatic (Vulcanian) or phreatomagmatic explosions which were probably induced by a shallow intrusive magma head.

Although the intermittent ash emission continued in a similar style, some changes in monitoring data were observed during Phase 3 (Fig. 9). The inflation of the volcanic edifice paused, $\mathrm{SO}_{2}$ emission decreased $(\sim 500$ ton/day: Fig. 2), and glowing of the crater was not observed during Phase 3 . These changes may indicate that the amount of the ascending magma decreased, leading to a decrease of the non-altered particles after the last day of the intermittent ash emission on December 13 (Phase 4: Fig. 8). The decrease of non-altered and partially altered particles and increase of highly altered particles (Type 3) in Phase 4 indicates that hydrothermal alteration (or sulfate mineral precipitation in other words) occurred during the interval between the last ash emission of Phase 3 (December 13) and the first explosion of Phase 4 (December 18; 5 days).

Phase 4 activities were characterized by explosive eruptions accompanied by PDCs and infrasound. These explosive activities were likely caused by the interaction between hot magma and a liquid phase hydrothermal fluid, as per the traditional explanation of phreatomagmatic eruptions (Schmincke 2004). There are two interpretations to consider for this change in eruption style. The first one is that the hydrothermal fluids did not exist during Phase 2 and recharged during Phase 3. Although a mechanism for recovery of the hydrothermal fluids is not clear, the edifice deflation during Phase 3 , which was likely caused by the pressure decrease 
around the conduit, may have resulted in infiltration of groundwater near the conduit to form a hydrothermal system (Fig. 9). The second interpretation is that before Phase 4 the conduit walls were sealed by the ascending magma, therefore contact with the right ratio of hydrothermal fluid was impossible. The cooling and retreating magma may have resulted in the depressurization of the conduit, thus allowing hydrothermal fluids and/ or groundwater to contact with magma. Although the second interpretation is also acceptable, it is difficult to explain the increase in sulfate-dominant particles and their textural changes (Type 3-2C to Type 3-2F).

The recovered hydrothermal fluid may be a sulfaterich brine as indicated by the mineral assemblage and leachate composition, which is characterized by low $\mathrm{Cl} /$ $\mathrm{SO}_{4}$ values $(<0.3)$ and high $\mathrm{SO}_{4}$ concentrations (8 wt. \% in maximum; Fig. 5 and Table 3). Large volume ratios of sulfate minerals to plagioclase up to 9 were observed during Phase 4 (Fig. 4). These sulfate minerals are mostly gypsum and anhydrite (Fig. 4 and Table 2) and appeared as fine aggregates of sulfate minerals (Type $3-2 \mathrm{~F}$; Fig. $7 \mathrm{~g}$ and $h$ ). This occurrence suggests that the fine sulfate and sulfide minerals precipitated directly from a saline hydrothermal fluid by rapid evaporation (Type 3-2F, Type 3-3 and Type 3-4; e.g., Zimbelman et al. 2005) and indicate that the hydrothermal fluid become sulfate- and sulfidesaturated after late Phase 3 (December 6, 2018). The low percentage of non-altered particles may indicate that the amount of new magma intrusion decreased and that the eruptive activity changed from magmatic to more hydrothermal. Precipitation of the abundant sulfate minerals may have caused choking of the volcanic conduit (e.g., Christenson 2000; Christenson et al. 2010; Mick et al. 2021), resulting in a change of eruption style from continuous ash emission (Phase 2 and 3) to intermittent explosive eruptions with repeated sealing and breaking of the seals (Phase 4: Fig. 9).

The volcanic ash of the eruption on December 28 is an exception of Phase 4 activity (Fig. 2). They contain nearly $10 \%$ non-altered particles with plagioclase as the dominant mineral assemblage (Figs. 4 and 8). This implies that a new magma intruded again around December 28. Alternatively, explosions may have excavated more material from the magma in the conduit.

\section{Effect of hydrothermal fluid for eruptive sequence and hazard implication}

As we discuss above, the 2018-2019 eruption of Kuchinoerabujima Volcano underwent an evolution in style from activity dominated by magma ascending at the beginning (Phases 1,2 and 3) to eruptions dominated by interaction between magma and hydrothermal fluids (Phase 4: Fig. 9). This change can be explained by a reduction in the magma supply from Phase 2 to Phase 4 . The hydrothermal system recovered after Phase 3 when the magma head descended, and the interaction between magma and hydrothermal fluid resulted in intense explosive activities during Phase 4 . The Phase 4 activities were accompanied by several PDCs, the largest of which occurred on January 17, 2019 with a runout distance of $1.9 \mathrm{~km}$ from the crater and $500 \mathrm{~m}$ short of the densely populated area of Mukaehama. It is an important finding from the viewpoint of volcanic disaster prevention that such violent volcanic phenomena can occur in the later phase of an eruption sequence. This study highlights the role that interaction between magma and hydrothermal fluids plays in controlling the eruption style. Therefore, undertaking detailed observation of the alteration products in volcanic ash is important for monitoring variations in the degree of interaction between shallow magma and a hydrothermal system, and therefore for forecasting changes in eruption style during eruption scenarios.

Hydrothermal system recovery has also been observed in the 1931-1945 and 1966-1980 eruptions of Kuchinoerabujima Volcano (Geshi et al. 2016) and some other volcanoes (e.g., the 2000 eruption of Usu Volcano: Ui et al. 2002; Tomiya and Miyagi 2002; the 2007 eruption of Ruapehu Volcano: Christenson et al. 2010; the 20102016 eruption of Turrialba Volcano: Alvarado et al., 2016; the 2016 eruption of Aso Volcano: Morita 2019). Transitions of eruption styles from magmatic to phreatic have also been interpreted from geological records at many volcanoes (e.g., Chokai Volcano 1801 eruption: Minami et al. 2019; Tokachidake Volcano 1962 eruption: Uesawa 2014; Okmok Volcano, Alaska: Wong and Larsen 2010; Cape Verde archipelago: Tarff and Day 2013). These examples suggest that recharge of hydrothermal fluids during an eruption sequence is a common phenomenon at active volcanoes.

\section{Conclusions}

Temporal changes in the componentry of volcanic ashes emitted during the 2018-2019 eruption at Kuchinoerabujima Volcano in Japan were investigated to understand the behaviors of magmas and hydrothermal fluids within the shallow conduit of the edifice. The eruption produced continuous ash-laden plume emission during Phase 2 and 3 , then the eruptive activity varied to intermittent explosive activity with several PDCs in Phase 4 . The proportion of non-altered and partially altered ash particles, indicative of magmatic materials was relatively high in Phase 2 and 3 , and it decreased in the later explosive Phase 4. Accordingly, mineral assemblages of the volcanic ashes changed from plagioclase-dominant to sulfate minerals-dominant. The concentration of $\mathrm{SO}_{4}{ }^{2-}$ and $\mathrm{Cl} / \mathrm{SO}_{4}$ values of the ashleachate samples decreased toward the later activity. These 
observations show that the 2018-2019 eruption of Kuchinoerabujima Volcano shifted from magmatic activities dominated by ascending juvenile magma at the beginning to phreatomagmatic activities driven by the interaction between magma and hydrothermal fluids towards the end of the sequence. Recovery of hydrothermal fluid in the upper conduit region during the eruption sequence caused the later phreatomagmatic activities. This case study serves as a pertinent recommendation that real-time description and interpretation of volcanic ash samples collected during an eruption scenario is a critical task for understanding and forecasting changes to magma-hydrothermal fluid interaction dynamics that can prevent volcanic disasters.

\section{Abbreviations}

AIST: National Institute of Advanced Industrial Science and Technology; JMA: Japan Meteorological Agency; PDCs: Pyroclastic density currents; GSJ: Geological Survey of Japan; SEM-EDS: Scanning electron microscope with energy-dispersive X-ray spectroscopy; XRD: X-ray diffractometer; GNSS: Global Navigation Satellite System.

\section{Acknowledgements}

We gratefully acknowledge the staff of Fukuoka Regional Headquarters, JMA who collected and provided ash samples. We would like to thank Dr. Chris Conway of Geological Survey of Japan for English language editing. The discussion with Dr. Junichi Itoh and Dr. Teruki Oikawa of Geological Survey of Japan were helpful for drafting. The authors would like to thank one anonymous reviewer and Dr. Dmitri Rouwet who significantly improved the manuscript and Dr. Atsuko Namiki for her handling and editing of the manuscript.

\section{Authors' contributions}

YM conceived the study and carried out the XRD analysis, the SEM-EDS analysis, and drafted the manuscript. KM described volcanic ash particles using optical microscope, micro-X-ray fluorescence instrument, and SEM-EDS. NG drafted geology of Kuchinoerabujima Volcano and arranged JMA negotiation. HS carried out chemical analysis of water-soluble species of volcanic ashes. All authors read and approved the final manuscript.

\section{Funding}

This study received no specific grant from any funding agency.

\section{Availability of data and materials}

The all of datasets used in this study are available from the corresponding author on reasonable request.

\section{Declarations}

Ethics approval and consent to participate

Not applicable.

\section{Consent for publication}

Not applicable.

\section{Competing interests}

The authors declare that they have no competing interests.

Received: 5 October 2021 Accepted: 12 January 2022

Published online: 30 January 2022

\section{References}

Alvarado G, Mele D, Dellino P, de Moor JM, Avard G (2016) Are the ashes from the latest eruptions (2010-2016) at Turrialba volcano (Costa Rica) related to phreatic or phreatomagmatic events? J Volcanol Geotherm Res 327:407-415

Caudron C, Girona T, Jolly A, Christenson B, Savage MK, Carniel R, Lecocq T, Kennedy B, Lokmer I, Yates A, Hamling I, Park I, Kilgour G, Mazot A (2021) A quest for unrest in multiparameter observations at Whakaari/White Island volcano, New Zealand 2007-2018. Earth Planets Space 73:195. https://doi.org/10.1186/s40623-021-01506-0

Christenson BW (2000) Geochemistry of fluids associated with the 1995-1996 eruption of Mt. Ruapehu, New Zealand: signatures and processes in the magmatic-hydrothermal system. J Volcanol Geotherm Res 97:1-30

Christenson BW, Reyes AG, Young R, Moebis A, Sherburn S, Cole-Baker J, Britten K (2010) Cyclic processes and factors leading to phreatic eruption events: Insights from the 25 September 2007 eruption through Ruapehu Crater Lake, New Zealand. J Volcanol Geotherm Res 191:15-32

Delmelle P, Henley R, Bernard A (2015) Volcano-related lakes. In: Sigurdsson $H$ (ed) The Encyclopedia of Volcanoes, 2nd edn. Academic Press, Cambridge, pp 851-864

Dempsey DE, Cronin SJ, Mei S, Kempa-Liehr AW (2020) Automatic precursor recognition and real-time forecasting of sudden explosive volcanic eruptions at Whakaari, New Zealand. Nat Commun 11:3562. https://doi.org/ 10.1038/s41467-020-17375-2

Geshi N, Itoh J (2018) Pyroclastic density currents associated with the 2015 phreatomagmatic eruption of Kuchinoerabujima volcano. Earth Planets Space 70:119. https://doi.org/10.1186/s40623-018-0881-x

Geshi N, Iguchi M, Shinohara H (2016) Phreatomagmatic eruptions of 2014 and 2015 in Kuchinoerabujima Volcano triggered by a shallow intrusion of magma. J Nat Dis Sci 37:67-78

Geshi N, Kobayashi T, (2007) Geological Map of Kuchinoerabujima Volcano (1:25,000). Geological Map of Volcanoes 14, Geological Survey of Japan, AIST. (in Japanese with English abstract)

Graettinger AH, Valentine GA, Sonder I (2016) Recycling in debris-filled volcanic vents. Geology 44:811-814

Hedenquist JW, Arribas A, Gonzalez-Urien E (2000) Exploration for epithermal gold deposits. Rev Econ Geol 13:245-277

Houghton BF, Smith RT (1993) Recycling of magmatic clasts during explosive eruptions: estimating the true juvenile content of phreatomagmatic volcanic deposits. Bull Volcanol 55:414-420

Inguaggiato C, Iñiguez E, Peiffer E, Kretzschmar T, Brusca L, Mora-Amador R, Ramirez C, Bellomo S, Gonzalez G, Rouwet D (2018) Gondwana Res 59:87-96

Japan Meteorological Agency (2018) Major eruptive activities in Japan in 2018, in "Monthly Volcanic Activity report, November 2018" 3pp. https://www. data.jma.go.jp/svd/vois/data/tokyo/eng/volcano_activity/2018/2018_ 11_monthly.pdf

Matsumoto A, Nakagawa M, Amma-Miyasaka M, Iguchi M (2013) Temporal Variations ofthe Petrological Features ofthe Juvenile Materials during 2006 to 2010 from Showa Crater, Sakurajima Volcano, Kyushu. Japan Bull Volcanol Soc Japan 58:191-212

Mick E, Stix J, de Moor M, Avard G (2021) Hydrothermal alteration and sealing at Turrialba volcano, Costa Rica, as a mechanism for phreatic eruption triggering. J Volcanol Geotherm Res 416:107297

Miki D, Iguchi M, Eto T, Solihim A (2002) Paleomagnetic ages of the lava flows of Shindake, Kuchinoerabujima. DPRI, Kyoto Univ. Kyoto. pp 159-168 (in Japanese). http://www.svo.dpri.kyoto-u.ac.jp/iwo_kuchi/19.pdf

Minami Y, Imura T, Hayashi S, Ohba T (2016) (2016) Mineralogical study on volcanic ash of the eruption on September 27, 2014 at Ontake volcano, central Japan: correlation with porphyry copper systems. Earth Planet Sp 68:67. https://doi.org/10.1186/s40623-016-0440-2

Minami Y, Ohba T, Hayashi S, Saito-Kokubu Y, Kataoka KS (2019) Lahar record during the last 2500 years, Chokai Volcano, northeast Japan: Flow behavior, sourced volcanic activity, and hazard implications. J Volcanol Geotherm Res 387:106661. https://doi.org/10.1016/j.jvolgeores.2019. 106661

Miyabuchi Y, Hanada D, Niimi H, Kobayashi T (2013) Stratigraphy, grain-size and component characteristics of the 2011 Shinmoedake eruption deposits, Kirishima Volcano, Japan. J Volcanol Geotherm Res 258:31-46

Morita M (2019) Temporal variations of plume activites before the 8 October 2016 eruption of Aso volcano, Japan, detected by ground-based and satellite measurements. Earth Planets Space 71:7. https://doi.org/10. 1186/s40623-019-0986-x 
Morrissey MM, Mastin LG (2000) Vulcanian eruptions. In: Sigurdsson H (ed) Encyclopedia of Volcanoes. Academic Press, San Diego, pp 463-476

Nakamichi H, Iguchi M, Taneguri T, Sonoda T (2017) Quantification of seismic and acoustic waves to characterize the 2014 and 2015 eruptions of Kuchinoerabujima Volcano, Japan. J Natural Disaster Sci 38:65-83

Németh K, Kósik S (2020) Review of explosive hydrovolcanism. Geosciences. https://doi.org/10.3390/geosciences 10020044

Nogami K, Yoshida M (1993) Leaching process of rock forming components through acidic alteration. Jour Chem Soc Japan 3:251-258

Ohba T (2011) hydrothermal mineral-bearing volcanic products: relationship with subvolcanic hydrothermal systems, and styles and patterns of their formation. Jour Geol Soc Japan 117:344-356 (in Japanese with English abstract)

Ohba T, Kitade Y (2005) Subvolcanic hydrothermal systems: Implications from hydrothermal minerals in hydrovolcanic ash. J Volcanol Geotherm Res 145:249-262

Ono K, Watanabe K, Hoshizumi H, Ikebe S (1995) Ash eruption of the Nakadake crater, Aso volcano, southwestern Japan. J Volcanol Geotherm Res 66:137-148

Ossaka J, Nogami K, Hirabayashi J (1998) Water-soluble components on volcanic ash from Tokachi-dake Volcano, Japan during the 1988-1989 eruption. Bull Volcanol Soc Japan 43:25-31 (in Japanese with English abstract)

Otálora F, García-Ruiz JM (2014) Nucleation and growth of the Naica giant gypsum crystals. Chem Soc Rev 43:2013-2026

Reed HM (1997) Hydrothermal alteration and its relationship to ore fluid composition. In: Barnes HL (ed) Geochemistry of hydrothermal ore deposits, 3rd edn. John Wiley and Sons, New York

Schmincke H-U (2004) Volcanism. Springer Science \& Business Media, Berlin

Shinohara H, Matsushima N, Kazahaya K, Ohwada M (2011) Magma-hydrothermal system interaction inferred from volcanic gas measurements obtained during 2003-2008 at Meakandake volcano, Hokkaido, Japan. Bull Volcanol 73:409-421. https://doi.org/10.1007/s00445-011-0463-2

Sillitoe RH (2010) Porphyry Copper Systems. Econ Geol 105:3-41. https://doi. org/10.2113/gsecongeo.105.1.3

Stix J, de Moor JM (2018) Understanding and forecasting phreatic eruptions driven by magmatic degassing. Earth Planets Space 70:83. https://doi. org/10.1186/s40623-018-0855-z

Stoffregen R (1987) Genesis of acid-sulfate alteration and Au-Cu-Ag mineralization at Summitville, Colorado. Econ Geol 82:1575-1591. https://doi.org/ 10.2113/gsecongeo.82.6.1575

Sugai A, Shinohara E, Nakamura M, Mori T, (2019) Eruptive activities of Kuchinoerabujuma volcano after 2018. In: Abstracts of the Volcanological Society of Japan the 2019 fall meeting, Kobe University, Kobe, 25-27 September. 2019 [in Japanese]

Tarff RW, Day SJ (2013) Chilled margin fragmentation as a trigger for transition from Strombolian to phreatomagmatic explosive activity at Cova de Paul Crater, Santo Antao. Cape Verde Islands Bull Volcanol 75:735. https://doi. org/10.1007/s00445-013-0735-0

Tomiya A, Miyagi I (2002) The eruptive products and magma process of March 31, 2000, eruption of Usu volcano. Bull Volcanol Soc Japan 47:663-673 (in Japanese with English abstract)

Uesawa S (2014) A study of the Taisho lahar generated by the 1926 eruption of Tokachidake Volcano, central Hokkaido, Japan, and implications for the generation of cohesive lahars. J Volcanol Geotherm Res 270:23-34

Ui T, Nakagawa M, Inaba C, Yoshimoto M, Geological party, Joint Research Group for the Usu 2000 Eruption (2002) Sequence of the 2000 Eruption. Usu Volcano. Bull. Volcanol. Soc. Japan 47:105-117 (in Japanese with English abstract)

van Hinsberg V, Berlo K, Pinti D, Ghaleb B (2021) Front. Earth Sci 9:764087. https://doi.org/10.3389/feart.2021.764087

White JDL, Ross PS (2011) Maar-diatreme volcanoes: A review. J Volcanol Geotherm Res 201:1-29

White JDL, Valentine GA (2016) Magmatic versus phreatomagmatic fragmentation: Absence of evidence is not evidence of absence. Geosphere 12:1478-1488. https://doi.org/10.1130/GES01337.1

Witham CS, Oppenheimer C, Horwell CJ (2005) Volcanic ash-leachates: a review and recommendations for sampling methods. J Volcanol Geotherm Res 141:299-326

Wohletz K, Heiken G (1992) Volcanology and geothermal energy. University of California Press
Wong LJ, Larsen JF (2010) The Middle Scoria sequence: A Hoocene violent strombolian, subplinian and phreatomagmatic eruption of Okmok volcano, Alaska. Bull Volcanol 72:17-31. https://doi.org/10.1007/ s00445-009-0301-y

Zimbelman DR, Rye RO, Breit GN (2005) Origin of secondary sulfate minerals on active andesitic stratovolcanoes. J Volcanol Geotherm Res 215:37-60

\section{Publisher's Note}

Springer Nature remains neutral with regard to jurisdictional claims in published maps and institutional affiliations.

\section{Submit your manuscript to a SpringerOpen ${ }^{\odot}$ journal and benefit from:}

- Convenient online submission

- Rigorous peer review

- Open access: articles freely available online

- High visibility within the field

- Retaining the copyright to your article

Submit your next manuscript at $\boldsymbol{\nabla}$ springeropen.com 